\title{
TAPIRIDAE (PERISSODACTYLA, MAMMALIA) OF THE SWISS MOLASSE BASIN DURING THE OLIGOCENE-MIOCENE TRANSITION
}

\author{
LAURELINE SCHERLER, ${ }^{*}, 1,2$ DAMIEN BECKER, ${ }^{2}$ and JEAN-PIERRE BERGER ${ }^{1}$ \\ ${ }^{1}$ Department of Geosciences-Earth Sciences, University of Fribourg, ch. du Musée 6, Pérolles 1700, Fribourg, Switzerland, \\ laureline.scherler@unifr.ch; jean-pierre.berger@unifr.ch; \\ ${ }^{2}$ Section d'archéologie et paléontologie du Jura, Office Cantonal de la Culture, Hôtel des Halles, CP34 2900, Porrentruy, \\ Switzerland, damien.becker@palaeojura.ch
}

\begin{abstract}
The Tapiridae of the Swiss Molasse Basin from the late Oligocene to the early Miocene are reviewed. Fossil remains that have not previously been described are identified, old descriptions and identifications from previous works are reassessed, and specimens from Switzerland and France are compared, specifically Protapirus bavaricus from EbnatKappel (MP28) and Rüfi bei Schänis (MP29), Protapirus aginensis from La Milloque (France, MP29), Protapirus douvillei from Buchberg 6 (MN4), Paratapirus helvetius from Haslen (Switzerland, MP28-30), Paratapirus intermedius from Saulcet (France, MN1), Höhronen (MN1), and Brüttelen 1 (MN3a), and Eotapirus broennimanni from Wischberg (MN1) and Benken (MN3-4?). These new data enable emended specific diagnoses for Protapirus bavaricus, P. aginensis, and P. douvillei. A late Oligocene (MP28-30) age for the locality of Haslen - the neotype locality of Paratapirus helvetius - is also attributed, based upon the literature and personal observations. Furthermore, a new and precise biostratigraphic range of the European Tapiridae at the species level is proposed for the Oligocene and early Miocene of Western Europe. The paleoecology of tapirs and their diversity and evolution through the Oligocene-Miocene transition are discussed and compared with contemporaneous large mammals such as Rhinocerotoidea, Anthracotheriidae, and Suoidea.
\end{abstract}

\section{INTRODUCTION}

Tapirids belong to the tapiroids, a basal perissodactyl group that flourished in the Eocene of Asia and North America (e.g., Prothero and Schoch, 1989; Schoch, 1989). The specific diversity of this lineage decreased drastically after the Oligocene. Today it is represented by only four living species in the monogeneric family Tapiridae Gray, 1821, that are distributed in Central and South America and Southeast Asia (Janis, 1984; Prothero and Schoch, 1989; Schoch, 1989). The Wasatchian genus Heptodon, considered by Holbrook (1999) as the earliest known member of the Tapiroidea, suggests that the ancestry of the Tapiridae could be traced back to the early Eocene from North America or Asia. However, Heptodon is considered by some authors (e.g., Colbert and Schoch, 1998; Colbert, 1999) as too primitive to be a tapiroid. Eberle (2005) hypothesized an origin from North America based upon the phylogenetically derived biogeographic reconstruction of the oldest and very primitive tapiroids Helaletes and Thuliadanta. The actual origin of the tapir is thus still in question. The oldest occurrence of Tapiridae is recorded in the early Oligocene of Europe, with the species Protapirus priscus in the fillings of Möhren 19 and 20, in Germany (Heissig, 1978, 1999a). Nevertheless, a European origin seems unlikely, given that tapiroids seem to be absent from this continent during the Eocene. The Lophiodontidae - which were predominant in Europe during the Eocene-are no longer considered as Tapiroidea, but as the sister group of Chalicotheridae (Hooker, 1989).

Despite numerous early analyses (Meyer, 1867; Filhol, 1874 1877, 1885; Gaudry, 1897; Depéret and Douxami, 1902; Schaub, 1928; Viret, 1929, 1958; von Koenigswald, 1930; Richard, 1938, 1948; Schaub and Hürzeler, 1948; Oettingen-Spielberg, 1952, 1958), the Oligocene and Miocene European fossil record of

${ }^{*}$ Corresponding author.
Tapiridae is very incomplete. The group has a sporadic record in the Oligocene and a limited radiation in the early Miocene. According to Heissig (1999a), the family seems absent after the Proboscidean Datum Event (17 Ma; Tassy, 1989)—excluding the isolated occurrence of Tapirus telleri in Göriach (MN6, Austria) - and only showed a short-term occurrence in the earliest late Miocene of Spain (Can Lobaretes, MN9), France (Priay, MN9?), Germany (Eppelsheim, Westhofen, Wissberg, MN9), Austria (Biedermannsdorf, MN9), and Hungary (Rudabanya, MN9; Czákvár, MN10-11). Since the first description by Kaup (1833) of a fossil representative-Tapirus priscus from the Dinotherium sands of Eppelsheim (late Miocene, MN9, Germany) - the true tapir species have suffered from numerous synonymies and the absence of a precise phylogeny. The most recent study on the systematics of European Tapiridae is by Cerdeño and Ginsburg (1988), who proposed to validate the three well-known genera Protapirus, Paratapirus, and Tapirus. They described a new genus Eotapirus, based upon the specimens from Pyrimont-Challonges (early Miocene, MN1, France) and Wischberg (early Miocene, MN1, Switzerland) earlier assigned to Paratapirus helvetius by Depéret and Douxami (1902) and Tapirus broennimanni by Schaub and Hürzeler (1948), respectively, and ascribed them to E. broennimanni. Cerdeño and Ginsburg (1988) also described the new species E. ruber from the Phosphorites du Quercy (Oligocene, France) and Protapirus cetinensis from Cetina de Aragón and Valquemado (early Miocene, MN2a, Spain). Unfortunately, they did not consider middle and late Miocene records. Only Heissig (1999a) presented the main distribution of the late Miocene Tapirus priscus and $T$. pannonicus in his short synthesis of Miocene European tapirs. In the Swiss Molasse Basin, tapirid localities are rare and recorded from only the late Oligocene, probably because the early Oligocene is predominantly marine facies (Berger et al., 2005). In most cases, the recorded material is isolated and fragmentary 
teeth (Aarwangen, MP27; Paudex, MP30; Benken, MN3-4?; Buchberg 6, MN4), fragmentary mandibles (Ebnat-Kappel, MP28; Wischberg, MN1; Höhronen, MN1; Brüttelen 1, MN3a; Würenlos, MN3), and fragmentary maxillae (Ebnat-Kappel, MP28; Rüfi bei Schänis, MP29). Two skulls with complete tooth rows have been discovered in Haslen (MP28-30) by Schaub (1928) and in Wischberg (MN1) by Schaub and Hürzeler (1948).

This study describes the tapir fossils of the Swiss Molasse Basin during the Oligocene-Miocene transition. Emended diagnoses for the species Protapirus bavaricus, $P$. aginensis, and $P$. douvillei are proposed. Based on new results and comparisons with the Western European record, a new and precise biostratigraphic range of the tapir species is established and their diversity and evolution are discussed.

\section{GEOLOGICAL SETTING}

All of the Swiss localities that contain tapirid fossils (Table 1) occur in the Molasse Basin (North Alpine Foreland Basin): Aarwangen (MP27), Ebnat-Kappel (MP28), Rüfi bei Schänis (MP29), Paudex (MP29), and Haslen (MP28-30) dated to the Chattian (late Oligocene), Wischberg (MN1) and Höhronen (Greit and Sparen) (MN1) dated to the Aquitanian (early Miocene), and Würenlos (MN3), Brüttelen 1 (MN3a), Benken (MN3-4?), and Buchberg 6 (MN4) dated to the Burdigalian (early Miocene) (Fig. 1). The French localities of La Milloque
(MP29; Chattian) and Saulcet (MN1; Aquitanian) are situated in the Aquitaine Basin and the Limagne Graben, respectively (Table 2).

\section{Oligocene Swiss Localities}

No tapir fossils have been discovered in the Rupelian of Switzerland (early Oligocene) and all of the Oligocene Swiss localities are dated to the Chattian (late Oligocene). They are precisely biostratigraphically dated (see Table 2 and Fig. 6 for stratigraphic correlations).

Aarwangen (Swiss national grid references 624.025/232.575) is the type locality of the Aarwanger Molasse, an equivalent of the Molasse alsacienne (Picot, 2002; Becker, 2003). It has been dated to the Mammal Biozone MP27 by Engesser and Mayo (1987). Ebnat-Kappel (727.880/235.040) belongs to the Ebnater Schichten and has been dated to the Mammal Biozone MP28 by Engesser and Mödden (1997). Rüfi bei Schänis (722.800/227.550) belongs to the Wintersberg Schichten from the USM (Lower Freshwater Molasse) and has been dated to the Mammal Biozone MP29 by Frei (1979) and Becker (2003). Paudex (541.200/151.720) belongs to the Molasse à Charbon and has been dated to the Mammal Biozone MP29 by Engesser et al. (1984) and Berger (1998).

The locality of Haslen (744-745/249-250) has been the subject of misunderstandings concerning its dating. The tapir remains were found in an isolated sandstone block along the Sitter

TABLE 1. Referred material and housing institutions.

\begin{tabular}{|c|c|c|c|c|c|c|}
\hline Species & Locality & Country & Anatomy & $\begin{array}{l}\text { Inventory } \\
\text { number }\end{array}$ & $\begin{array}{c}\text { Direct } \\
\text { observation }\end{array}$ & Housing Institution \\
\hline \multirow[t]{7}{*}{ Protapirus bavaricus } & \multirow[t]{6}{*}{ Ebnat-Kappel } & \multirow[t]{6}{*}{ Switzerland } & Mandible & EKO-T1 & Yes & Private collection U. Oberli \\
\hline & & & Fragmentary mandible & EKO-T2 & Yes & Private collection U. Oberli \\
\hline & & & Fragmentary mandible & EKO-T3 & Yes & Private collection U. Oberli \\
\hline & & & Fragmentary maxilla & EKO-T4 & Yes & Private collection U. Oberli \\
\hline & & & Fragmentary maxilla & EKO-T5 & Yes & Private collection U. Oberli \\
\hline & & & Lower incisor & EKO-T6 & Yes & Private collection U. Oberli \\
\hline & Rüfi bei Schänis & Switzerland & Fragmentary maxilla & $\mathrm{A} / \mathrm{V} 79$ & Yes & PIMUZ \\
\hline \multirow{4}{*}{ Protapirus aginensis } & \multirow{4}{*}{ La Milloque } & \multirow{4}{*}{ France } & Lower premolar & $\mathrm{Lm} 420$ & Yes & NMB \\
\hline & & & Lower premolar & $\mathrm{Lm} 421$ & Yes & NMB \\
\hline & & & Upper molar & $\mathrm{Lm} 422$ & Yes & NMB \\
\hline & & & Upper molar & Lm1404 & Yes & NMB \\
\hline Protapirus douvillei & Buchberg 6 & Switzerland & Upper premolar & A/V690 & Yes & PIMUZ \\
\hline \multirow[t]{2}{*}{ Paratapirus helvetius } & \multirow[t]{2}{*}{ Haslen } & \multirow[t]{2}{*}{ Switzerland } & Skull with maxillae & $\mathrm{P} 1500$ & Yes & NMSG \\
\hline & & & Fragmentary mandible & $\mathrm{P} 1501$ & Yes & NMSG \\
\hline \multirow{10}{*}{$\begin{array}{l}\text { Paratapirus } \\
\quad \text { intermedius }\end{array}$} & \multirow[t]{6}{*}{ Höhronen, Greit } & \multirow[t]{6}{*}{ Switzerland } & Fragmentary mandible & A/V0061 & Yes & PIMUZ \\
\hline & & & Fragmentary mandible & A/V0063 & Yes & PIMUZ \\
\hline & & & Fragmentary mandible & A/V64 & Yes & PIMUZ \\
\hline & & & Fragmentary mandible & A/V0065 & Yes & PIMUZ \\
\hline & & & Mandible & A/V148 & Yes & PIMUZ \\
\hline & & & Fragmentary maxilla & A/V64 & Yes & PIMUZ \\
\hline & Höhronen, Sparen & Switzerland & Fragmentary mandible & A/V0062 & Yes & PIMUZ \\
\hline & \multirow[t]{2}{*}{ Brüttelen 1} & \multirow[t]{2}{*}{ Switzerland } & Fragmentary mandible & 501454 & Yes & NMBE \\
\hline & & & Fragmentary tibia & 501453 & Yes & NMBE \\
\hline & Saulcet & France & Fragmentary mandible & Sau2282 & Yes & NMB \\
\hline \multirow{9}{*}{$\begin{array}{l}\text { Eotapirus } \\
\quad \text { broennimanni }\end{array}$} & \multirow[t]{5}{*}{ Wischberg } & \multirow[t]{5}{*}{ Switzerland } & Upper incisor & D3394 & Yes & NMBE \\
\hline & & & Fragmentary mandible & D3395 & Yes & NMBE \\
\hline & & & $\begin{array}{l}\text { Juvenile skull with } \\
\text { maxillae }\end{array}$ & As7 & Yes & NMB \\
\hline & & & Fragmentary mandible & As7 & Yes & NMB \\
\hline & & & Fragmentary mandible & As7 & Yes & NMB \\
\hline & \multirow[t]{4}{*}{ Benken } & \multirow[t]{4}{*}{ Switzerland } & Upper premolar & $\mathrm{A} / \mathrm{V} 1781$ & Yes & PIMUZ \\
\hline & & & Lower molar & A/V1782 & Yes & PIMUZ \\
\hline & & & Lower molar & $\mathrm{A} / \mathrm{V} 1782$ & Yes & PIMUZ \\
\hline & & & Upper molar & A/V1782 & Yes & PIMUZ \\
\hline \multirow[t]{3}{*}{ Tapiridae indet. } & Aarwangen & Switzerland & Upper molar & AW35 & Yes & NMB \\
\hline & Paudex & Switzerland & $\begin{array}{l}\text { Fragmentary upper } \\
\text { molar }\end{array}$ & v4108 & Yes & MHNG \\
\hline & Würenlos & Switzerland & Fragmentary mandible & $\mathrm{A} / \mathrm{V} 0075$ & Yes & PIMUZ \\
\hline
\end{tabular}




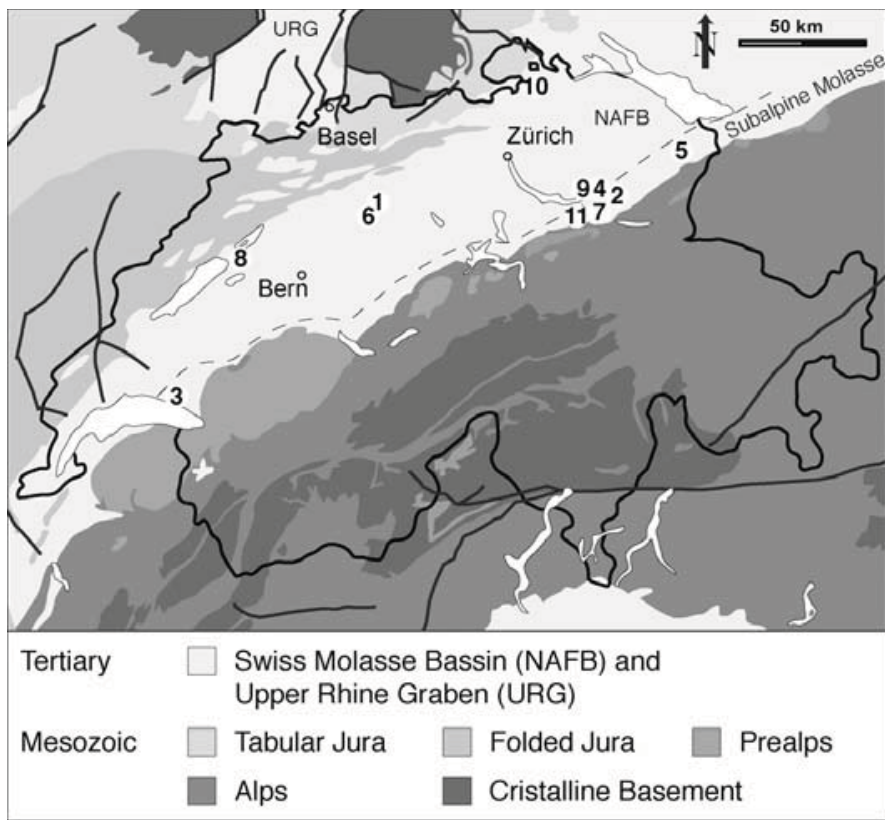

FIGURE 1. Geographic and geological setting of the Swiss Tapiridae localities (modified geological map according to the "Esquisse géologique de la Suisse," Ed. Swisstopo). 1, Aarwangen; 2, Ebnat-Kappel; 3, Paudex; 4, Rüfi bei Schänis; 5, Haslen; 6, Wischberg; 7, Höhronen; 8, Brüttelen 1; 9, Würenlos; 10, Benken; 11, Buchberg 6. Abbreviations: NAFB, North Alpine Foreland Basin; URG, Upper Rhine Graben.

River, upstream of the Rotbach confluence (Schaub, 1928). The surrounding Kalksandstein Formation is dated to the Chattian (Ludwig et al., 1949). According to Baumberger in Schaub's article on the tapir from Haslen (1928), the block matrix probably also belonged to the Kalksandstein Formation. As there are no such sediments in the OMM (Upper Marine Molasse) of the region, the latter doubtless came from the Chattian outcrop near the village of Haslen. A thin section of the block matrix confirmed this Chattian age, not providing any trace of glauconite nor marine fossils; this sandstone was effectively of fluviatile origin and its belonging to the OMM is, again, excluded. Therefore, a late Chattian (MP28-30) age is the most probable age for this locality. A Burdigalian age, as previously supposed by Cerdeño and Ginsburg (1988), is completely excluded.

\section{Miocene Swiss Localities}

Wischberg (624.650/227.630) belongs to the Obere Bunte Mergel from the Aquitanian USM and has been dated to the Mammal Biozone MN1 by Engesser and Mödden (1997). Höhronen (Greit and Sparen) (691.475/223.800 and 692.600/224.175) belongs to the Molasse Grise from the USM and has been dated to the Mammal Biozone MN1 by Engesser and Mödden (1997). Brüttelen 1 (576.800/207.050) belongs to the Sense Schichten from the Burdigalian OMM and has been dated to the Mammal Biozone MN3a by Engesser (1990). Würenlos (669.300/255.720) belongs to the Muschelsandstein Formation from the OMM and is therefore attributed to the Burdigalian (Müller et al., 1984) and probably to the Mammal Biozone MN3. Buchberg 6 (759.210/261.020) belongs to the OSM (Upper Freshwater Molasse) and has been dated by Bolliger (1997) to the Mammal Biozone MN4.

Benken (692.200/278.900) belongs to the St. Galler Schichten from the OMM and the Krokodilen Schichten have been dated to the Mammal Biozones MN3-4 by Bolliger (1992). Neverthe-
A
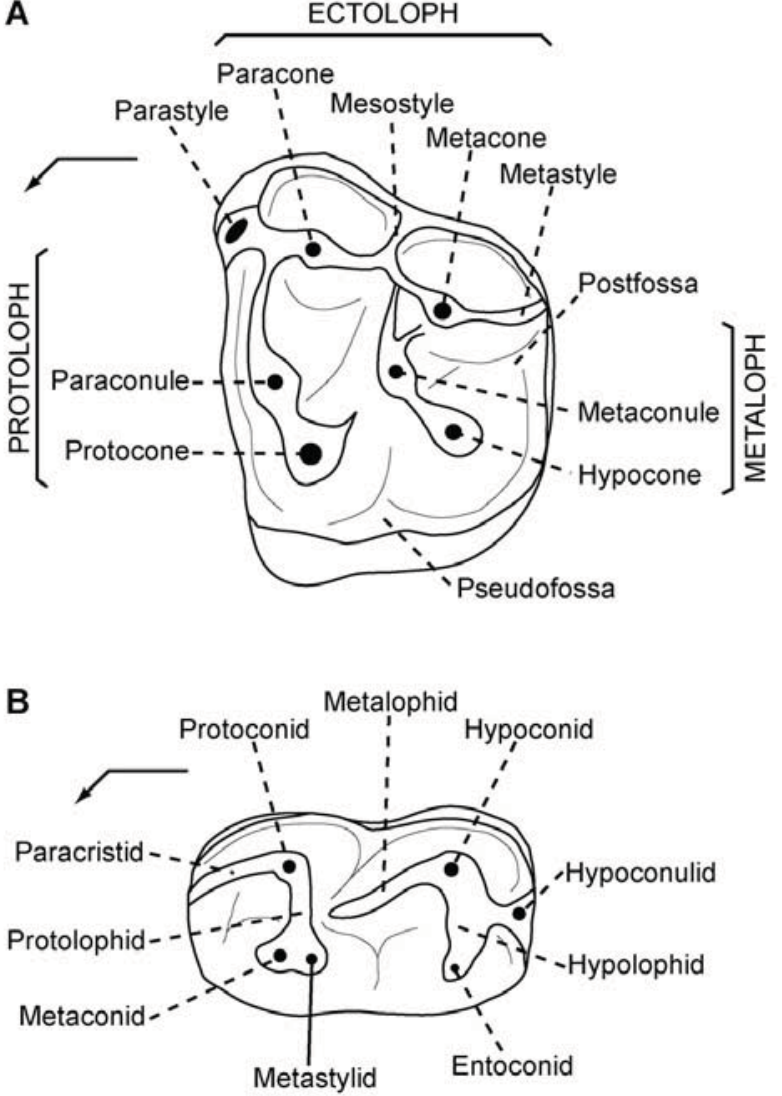

FIGURE 2. Tooth terminology for perissodactyls (modified from Hooker, 1989). A, left upper second molar; B, right lower second molar. Arrows indicate the mesiolingual side of the teeth.

less, Engesser (1990) mentioned a reworked fauna from the late Oligocene and the Aquitanian. The species Eotapirus broennimanni, as identified at Benken, had so far only been discovered in Wischberg and Pyrimont-Challonges, both dated to the Mammal Biozone MN1. Therefore, the tapir remains from Benken cannot be dated with certainty.

\section{MATERIALS AND METHODS}

The referred materials of this study (Table 1) have been partly published in the 19th and 20th centuries (e.g., Meyer, 1867; Schaub, 1928; Schaub and Hürzeler, 1948; Cerdeño and Ginsburg, 1988), but no recent work proposes a complete review. An inventory of the record of European tapirs is presented in Table 2. The private collection of Urs Oberli (St. Gallen) is a non-profit institution and is accessible to all. Visits can be arranged with the Naturhistorisches Museum of St. Gallen.

Taxonomy-The identifications are based upon comparative anatomy, biometric measurements, and the main diagnostic characters reviewed by Cerdeño and Ginsburg (1988). Tooth terminology follows Hooker (1989; Fig. 2). Biometric measurements have an accuracy of $0.5 \mathrm{~mm}$. Length is measured through the ectoloph where the tooth is the longest, width where the tooth is the widest (either through the protoloph or the metaloph), and height (only on unworn or slightly worn teeth) from the base of the crown to the highest cusp (usually the paracone for upper cheek teeth and the protoconid for lower cheek teeth). 
TABLE 2. Oligocene and early Miocene European localities recording tapirid fossils, with referred literature.

\begin{tabular}{|c|c|c|c|c|c|}
\hline $\begin{array}{l}\text { Species (*type } \\
\text { species) }\end{array}$ & $\begin{array}{l}\text { Locality }(* \text { type and } \\
* * \text { neotype locality) }\end{array}$ & Country & Age & $\begin{array}{l}\text { Mammal } \\
\text { Zone }\end{array}$ & References \\
\hline \multirow[t]{2}{*}{$\begin{array}{l}\text { Protapirus } \\
\text { priscus* }\end{array}$} & Caylux* & France & Oligocene & - & $\begin{array}{l}\text { Filhol, 1874, 1877, 1885; Gaudry, 1897; Zittel, 1894; } \\
\text { Depéret and Douxami, 1902; Schaub, 1928; Viret, } \\
\text { 1929; von Koenigswald, 1930; Oettingen-Spielberg, } \\
\text { 1958; Cerdeño and Ginsburg, } 1988\end{array}$ \\
\hline & Möhren 19, 20 & Germany & Rupelian & MP21 & Heissig, 1978, 1999a \\
\hline \multirow[t]{3}{*}{$\begin{array}{l}\text { Protapirus } \\
\quad \text { bavaricus }\end{array}$} & Gaimersheim* & Germany & Chattian & MP27 & $\begin{array}{l}\text { Schaub, 1928; Oettingen-Spielberg, 1952, 1958; Viret, } \\
\text { 1958; Cerdeño and Ginsburg, 1988; } \\
\text { Schmidt-Kittler et al., } 1997\end{array}$ \\
\hline & Ebnat-Kappel & Switzerland & Chattian & MP28 & $\begin{array}{l}\text { Engesser and Mödden, 1997; Schmidt-Kittler et al., } \\
\text { 1997; this study }\end{array}$ \\
\hline & Rüfi bei Schänis & Switzerland & Chattian & MP29 & $\begin{array}{l}\text { Schaub, 1928; Oettingen-Spielberg, 1952, 1958; Frei, } \\
\text { 1979; Cerdeño and Ginsburg, 1988; Becker, 2003; } \\
\text { this study }\end{array}$ \\
\hline $\begin{array}{l}\text { Protapirus } \\
\quad \text { aginensis }\end{array}$ & La Milloque* & France & Chattian & MP29 & $\begin{array}{l}\text { Schaub, 1928; Richard, 1938, 1948; } \\
\text { Oettingen-Spielberg, 1958; Cerdeño and Ginsburg, } \\
\text { 1988; Schmidt-Kittler et al., 1997; this study }\end{array}$ \\
\hline \multirow[t]{5}{*}{$\begin{array}{l}\text { Protapirus } \\
\quad \text { douvillei }\end{array}$} & Saint-Gérand-le-Puy* & France & Aquitanian & $\mathrm{MN} 2 \mathrm{a}$ & $\begin{array}{l}\text { Filhol, 1885; Gaudry, 1897; Depéret and Douxami, } \\
\text { 1902; Schaub, 1928; Viret, 1929; } \\
\text { Oettingen-Spielberg, 1958; Cerdeño and Ginsburg, } \\
\text { 1988; Heissig, } 1999\end{array}$ \\
\hline & Paulhiac & France & Aquitanian & MN1 & Schaub, 1928; Oettingen-Spielberg, 1952; Mein, 1989 \\
\hline & Montaigu & France & Aquitanian & $\mathrm{MN} 2 \mathrm{a}$ & $\begin{array}{l}\text { Schaub, 1928; Oettingen-Spielberg, 1952; Hugueney, } \\
1997\end{array}$ \\
\hline & Fontcaude & France & $\begin{array}{l}\text { 'mid' } \\
\text { Aquitanian }\end{array}$ & - & Roman, 1919; Cerdeño and Ginsburg, 1988 \\
\hline & Buchberg 6 & Switzerland & Burdigalian & MN4 & Bolliger, 1997; this study \\
\hline \multirow[t]{2}{*}{$\begin{array}{l}\text { Protapirus } \\
\quad \text { cetinensis }\end{array}$} & Cetina de Aragon* & Spain & Aquitanian & MN2a & $\begin{array}{l}\text { Cerdeño and Morales, 1986; Cerdeño, 1988; Cerdeño } \\
\text { and Ginsburg, 1988; Heissig, } 1999\end{array}$ \\
\hline & Valquemado & Spain & Aquitanian & $\mathrm{MN} 2 \mathrm{a}$ & Cerdeño and Ginsburg, 1988 \\
\hline Protapirus sp. & Espenhain & Germany & Rupelian & MP22 & Böhme, 2001 \\
\hline \multirow[t]{2}{*}{$\begin{array}{l}\text { Paratapirus } \\
\quad \text { helvetius }\end{array}$} & Othmarsingen* & Switzerland & 'late' Chattian & - & $\begin{array}{l}\text { Meyer, 1867; Gaudry, 1897; Depéret and Douxami, } \\
1902\end{array}$ \\
\hline & Haslen** & Switzerland & Chattian & MP28-30 & $\begin{array}{l}\text { Schaub, 1928; Viret, 1929, 1958; Oettingen-Spielberg, } \\
\text { 1952; Cerdeño and Ginsburg, 1988; this study }\end{array}$ \\
\hline \multirow[t]{14}{*}{$\begin{array}{l}\text { Paratapirus } \\
\quad \text { intermedius }\end{array}$} & Selles-sur-Cher* & France & Aquitanian & $\mathrm{MN} 2 \mathrm{~b}$ & $\begin{array}{l}\text { Filhol, 1885; Zittel, 1894;Depéret and Douxami, } \\
\text { 1902; Stehlin, 1909; Schaub, 1928; } \\
\text { Oettingen-Spielberg, 1952; Ginsburg and } \\
\text { Hugueney, 1980; Cerdeño and Ginsburg, 1988; } \\
\text { Heissig, 1999 }\end{array}$ \\
\hline & Höhronen, Greit & Switzerland & Aquitanian & MN1 & $\begin{array}{l}\text { Meyer, 1867; Depéret and Douxami, 1902; Engesser } \\
\text { and Mödden, 1997; this study }\end{array}$ \\
\hline & Höhronen, Sparen & Switzerland & Aquitanian & MN1 & Meyer, 1867; Engesser and Mödden, 1997; this study \\
\hline & Saulcet & France & Aquitanian & MN1 & Viret and Hürzeler, 1937; Mein, 1989; this study \\
\hline & $\begin{array}{l}\text { Eggingen- } \\
\text { Gemeindesteinbruch }\end{array}$ & Germany & Aquitanian & MN2 & $\begin{array}{l}\text { Meyer, 1867; Depéret and Douxami, 1902; von } \\
\text { Koenigswald, 1930; Cerdeño and Ginsburg, 1988; } \\
\text { Heissig, 1999 }\end{array}$ \\
\hline & Hessler & Germany & Aquitanian & $\mathrm{MN} 2 \mathrm{~b}$ & $\begin{array}{l}\text { von Koenigswald, 1930; Cerdeño and Ginsburg, 1988; } \\
\text { Heissig, } 1999\end{array}$ \\
\hline & Budenheim & Germany & Aquitanian & $\mathrm{MN} 2 \mathrm{~b}$ & $\begin{array}{l}\text { von Koenigswald, 1930; Cerdeño and Ginsburg, 1988; } \\
\text { Heissig, } 1999\end{array}$ \\
\hline & Haslach & Germany & Aquitanian & $\mathrm{MN} 2 \mathrm{~b}$ & $\begin{array}{l}\text { Meyer, 1867; Depéret and Douxami, 1902; von } \\
\text { Koenigswald, 1930; Cerdeño and Ginsburg, } 1988\end{array}$ \\
\hline & Eselsberg & Germany & Aquitanian & $\mathrm{MN} 2 \mathrm{~b}$ & $\begin{array}{l}\text { Zittel, 1894; von Koenigswald, 1930; Cerdeño and } \\
\text { Ginsburg, } 1988\end{array}$ \\
\hline & Brux & France & Aquitanian & - & $\begin{array}{l}\text { Schlosser, 1910; von Koenigswald, 1930; Cerdeño and } \\
\quad \text { Ginsburg, } 1988\end{array}$ \\
\hline & Laugnac & France & Aquitanian & MN2b & Viret, 1929; Cerdeño and Ginsburg, 1988; Mein, 1989 \\
\hline & Brüttelen 1 & Switzerland & Burdigalian & MN3a & $\begin{array}{l}\text { Studer, 1895; Berger, 1985; Engesser, 1990; Kälin, } \\
\text { 1997; this study }\end{array}$ \\
\hline & Faluns Touraine/Anjou & France & Burdigalian & MN4a & $\begin{array}{l}\text { Ginsburg, 1980; Ginsburg et al., 1982; Cerdeño and } \\
\text { Ginsburg, } 1988\end{array}$ \\
\hline & Eggingen-Mittelhart 3 & Germany & Burdigalian & MN4 & Sach and Heizmann, 2001 \\
\hline \multirow[t]{3}{*}{$\begin{array}{l}\text { Eotapirus } \\
\quad \text { broennimanni* }\end{array}$} & Pyrimont-Challonges* & France & Aquitanian & MN1 & $\begin{array}{l}\text { Depéret and Douxami, 1902; Viret and Hürzeler, } \\
\text { 1937; Schaub and Hürzeler, 1948; Cerdeño and } \\
\text { Ginsburg, 1988; Mein, 1989; Heissig, } 1999\end{array}$ \\
\hline & Wischberg & Switzerland & Aquitanian & MN1 & $\begin{array}{l}\text { Schaub and Hürzeler, 1948; Cerdeño and Ginsburg, } \\
\text { 1988; Engesser and Mödden, 1997; Heissig, 1999; } \\
\text { this study }\end{array}$ \\
\hline & Benken & Switzerland & Burdigalian? & MN3-4? & $\begin{array}{l}\text { Engesser, 1990; Bolliger, 1992; Bolliger, 1997; this } \\
\text { study }\end{array}$ \\
\hline Eotapirus ruber & Phosphorites du Quercy* & France & Oligocene & - & Cerdeño and Ginsburg, 1988 \\
\hline \multirow{4}{*}{ Tapiridae indet. } & Vaumas & France & Oligocene & MP25? & Pomel, 1853; Hugueney, 1997 \\
\hline & Aarwangen & Switzerland & Chattian & MP27 & Engesser and Mayo, 1987; this study \\
\hline & Paudex & Switzerland & Chattian & MP29 & Engesser et al., 1984; Berger, 1998; this study \\
\hline & Würenlos & Switzerland & Burdigalian & MN3 & Müller et al., 1984; this study \\
\hline
\end{tabular}


Biostratigraphy - The biochronological framework is based on the chronological correlations of the Paleogene and Neogene European Land Mammal Zones (MP-Levels and MN-Zones; Mein, 1999; Steininger, 1999; Luterbacher et al., 2004).

Paleoecology-The ecology of the fossil tapir species is extrapolated from the ecology of the associated large-mammal taxa compiled from the literature data (Hellmund, 1991; Fortelius et al., 1996; Becker, 2003; Ginsburg and Chevrier, 2005; B. Mennecart, pers. comm.). The habitats are defined according to the vegetation cover (closed, intermediate, open, not specified) and the relation to water (dry, humid/wet, semi-aquatic, not specified). The ecology of the whole community determines the main paleoecological conditions.

Oligocene-Miocene Transition-The fossil record comprises primarily four large-mammal clades (Tapiridae, Rhinocerotoidea, Anthracotheriidae, Suoidea) of Western Europe in the Oligocene and the early Miocene. The diversity and evolution are based upon FAD (First Appearance Datum) and LAD (Last Appearance Datum) and are compiled from the literature updated with the new tapir data in this paper and personal observations in the Swiss Molasse Basin record.

Institutional Abbreviations-NMB, Naturhistorisches $\mathrm{Mu}-$ seum Basel (Switzerland); NMBE, Naturhistorisches Museum der Burgergemeinde Bern (Switzerland); PIMUZ, Paläontologisches Institut und Museum der Universität Zürich (Switzerland); NMSG, Naturhistorisches Museum Sankt Gallen; MHNG, Muséum d'histoire naturelle de Genève.

Anatomical Abbreviations-I/i, upper/lower incisor; C/c, upper canine; $\mathbf{P} / \mathbf{p}$, upper/lower premolar; $\mathbf{M} / \mathbf{m}$, upper/lower molar; D/d, upper/lower deciduous tooth.

\section{SYSTEMATIC PALEONTOLOGY}

Order PERISSODACTYLA Owen, 1848 Suborder TAPIROMORPHA Haeckel, 1866 Infraorder CERATOMORPHA Wood, 1937

Superfamily TAPIROIDEA Gray, 1821

Family TAPIRIDAE Gray, 1821 Genus PROTAPIRUS Filhol, 1877

Type Species-Protapirus priscus (Filhol, 1874) from the Phosphorites du Quercy, France (Oligocene).

Other Species Referred to the Genus- $P$. bavaricus (Oettingen-Spielberg, 1952), $P$. aginensis (Richard, 1938), P. cetinensis Cerdeño and Ginsburg, 1988, P. douvillei (Filhol, 1885).

Distribution-Early Oligocene to early Miocene of Europe; late Oligocene of North America (Schoch, 1989).

Diagnosis - Small to medium-sized Tapiridae; un- or weakly molarized upper premolars; lingually convergent protoloph and metaloph on $\mathrm{P} 2, \mathrm{P} 3$, and $\mathrm{P} 4$, with protocone and hypocone closing the median valley; skull with incipient proboscis (translation of Cerdeño and Ginsburg, 1988:3).

\section{PROTAPIRUS BAVARICUS (Oettingen-Spielberg, 1952)} (Fig. 3; Table 3)

Type Locality-Gaimersheim bei Ingolstadt, Germany (late Oligocene, MP27)

Synonymy—See Cerdeño and Ginsburg (1988:4) for recent synonymy list.

Distribution-Late Oligocene of Germany and Switzerland (Schaub, 1928; Oettingen-Spielberg, 1952, 1958; Viret, 1958; Cerdeño and Ginsburg, 1988; this study) (Table 2).

Emended Diagnosis-Larger than Protapirus priscus; slightly less fused protocone and hypocone on P3 and P4 than in Protapirus priscus but more than in Protapirus aginensis (translation of Cerdeño and Ginsburg, 1988:5); undeveloped postfossa and absence of lingual pseudofossa on upper premolars.
Referred Specimens-Ebnat-Kappel (Switzerland, MP28; Private collection of Urs Oberli, St. Gallen): incomplete right mandible with p2-m3 (EKO-T1), fragmentary left mandible with $\mathrm{m} 3$ (EKO-T2), fragmentary left mandible with $\mathrm{m} 2$ (EKO-T3), fragmentary left maxilla with P1-P4 (EKO-T4), fragmentary right maxilla with M1-M3 (EKO-T5), left i1 (EKO-T6); Rüf bei Schänis (Switzerland, MP29): fragmentary left maxilla with P3-M3 and roots of P1 and P2 (PIMUZ-A/V79).

\section{Description}

Upper Dentition - P1 is elongated and triangular, not molarized, with slightly oblique ectoloph. The paracone and metacone are closed, there is a lingual fossa with slightly raised internal wall, a weak parastyle, and no cingula. P2 is subtriangular, not molarized, with slightly oblique ectoloph. The reduced and oblique protoloph and straight metaloph are lingually convergent, and the protocone and hypocone are fused, lingually closing the median valley. The anterior and lingual cingula are not visible (worn tooth), but there is a weak parastyle, a weak continuous posterior cingulum (from the middle of the metacone to the middle of the hypocone), and a subhorizontal and weak posterior labial cingulum around the metacone and joining the posterior cingulum. The postfossa is undeveloped. P3 and $\mathrm{P} 4$ are subrectangular, not molarized, with slightly oblique ectoloph. The oblique protoloph and straight metaloph are lingually convergent, and the protocone and hypocone are fused, lingually closing the median valley. There is a weak parastyle, a continuous anterior cingulum (from the parastyle to the middle of the protocone) weak on $\mathrm{P} 3$ but slightly developed on $\mathrm{P} 4$, a continuous posterior cingulum (from the middle of the metacone to the middle of the hypocone) slightly developed on P3 but developed on $\mathrm{P} 4$, an oblique posterior labial cingulum around the metacone and joining the posterior cingulum, weak on P3 but slightly developed on $\mathrm{P} 4$, and a short and weak lingual cingulum. The postfossa is undeveloped. M1, M2, and M3 are trapezoidal, with a strongly oblique ectoloph. The reduced and oblique metaloph and lesser oblique protoloph are lingually divergent, and the protocone and hypocone are unfused and well separated, allowing the lingual opening of the median valley. There is a well-developed parastyle on M1 and M2, but strongly developed on M3, a continuous anterior cingulum (from the parastyle to the middle of the protocone) slightly developed on M1 but well developed on M2 and M3, a continuous and developed posterior cingulum (from the middle of the metacone to the middle of the hypocone) on M1 and M2, but short (only at the level of the metacone) and slightly developed on M3, a subhorizontal and slightly developed posterior labial cingulum around the metacone and joining the posterior cingulum, and a short and slightly oblique lingual cingulum, slightly developed on M1 but weak on M2 and M3. The postfossa is undeveloped.

Lower Dentition - p2 is not molarized, with an isolated entoconid (conical entoconid and hypoconid not fused in a hypolophid) and a well-developed paracristid elongated in a paralophid. The cingulids are not visible (worn tooth). p3 and p4 are not molarized, with an isolated entoconid (conical entoconid and hypoconid and not fused in a hypolophid), and a talonid wider than trigonid. The paracristid is developed, and the protolophid is slightly concave. There is a short and weak anterior cingulid on p3 (character not visible on p4), a short and weak posterior cingulid on $\mathrm{p} 3$ (character not visible on $\mathrm{p} 4$ ), a short labial cingulid at the level of the median valley weak on $\mathrm{p} 3$ but slightly developed on $\mathrm{p} 4$, and no lingual cingulid. $\mathrm{m} 1, \mathrm{~m} 2$, and $\mathrm{m} 3$ have a developed paracristid on $\mathrm{m} 2$ and $\mathrm{m} 3$ (character not visible on $\mathrm{m} 1$ ), a trigonid wider than talonid, and two subvertical crests on the posterior side of the protolophid. The metastylid is slightly developed, the 
TABLE 3. Dental measurements (in $\mathrm{mm}$ ) of the studied tapir species; range values are in brackets when more than one sample is used for the averaging dimension.

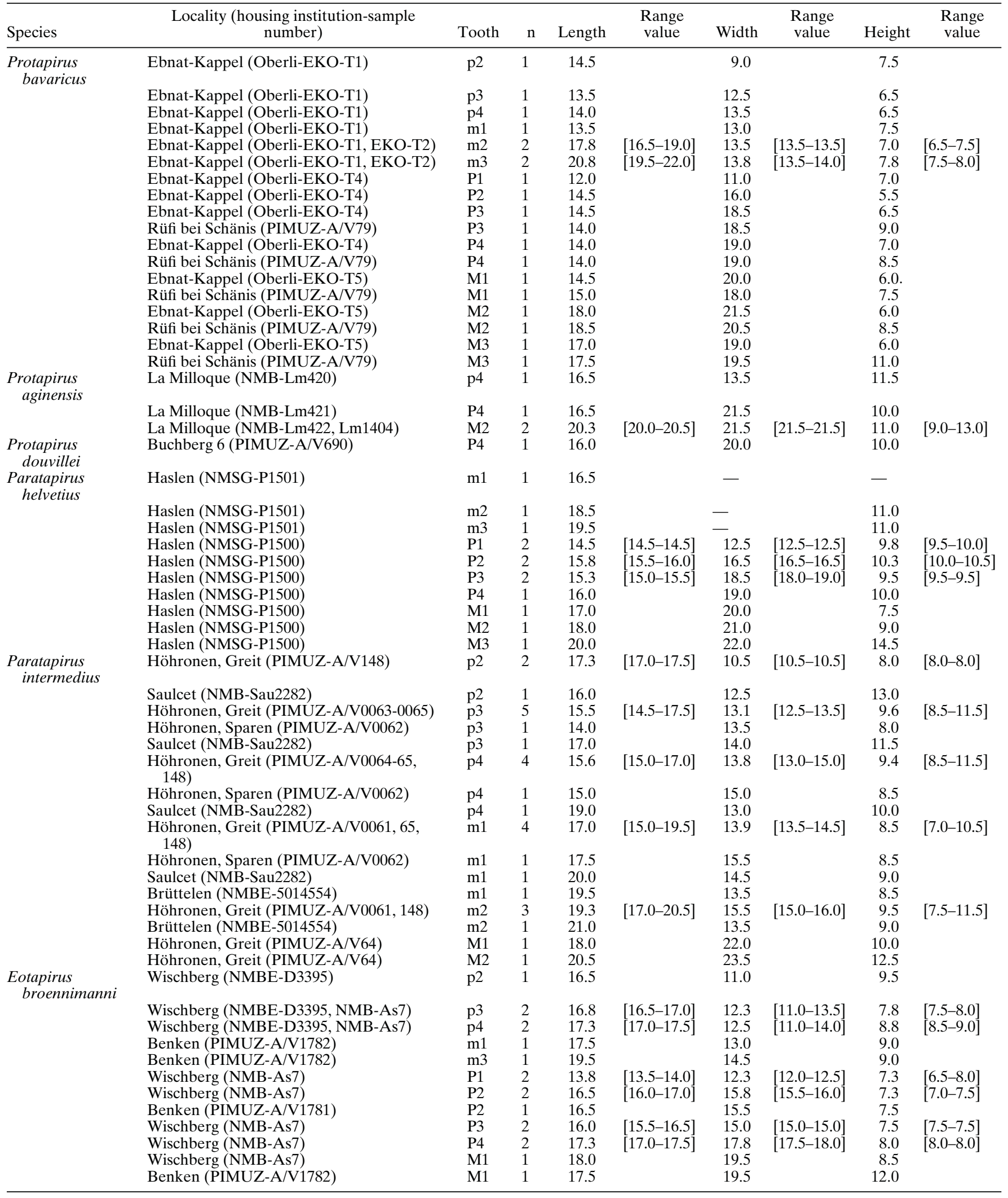




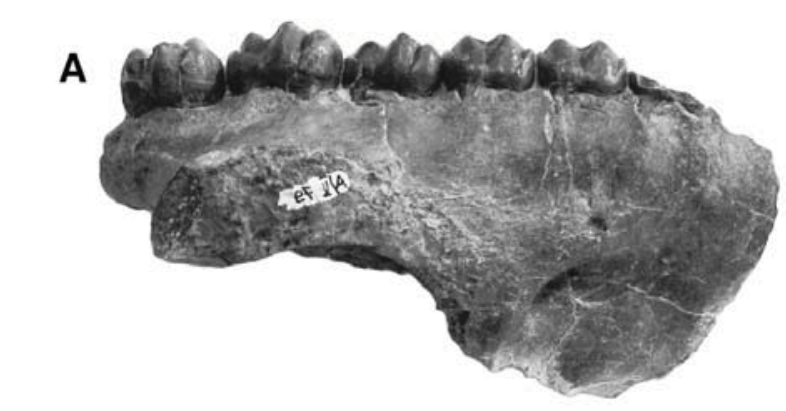

C
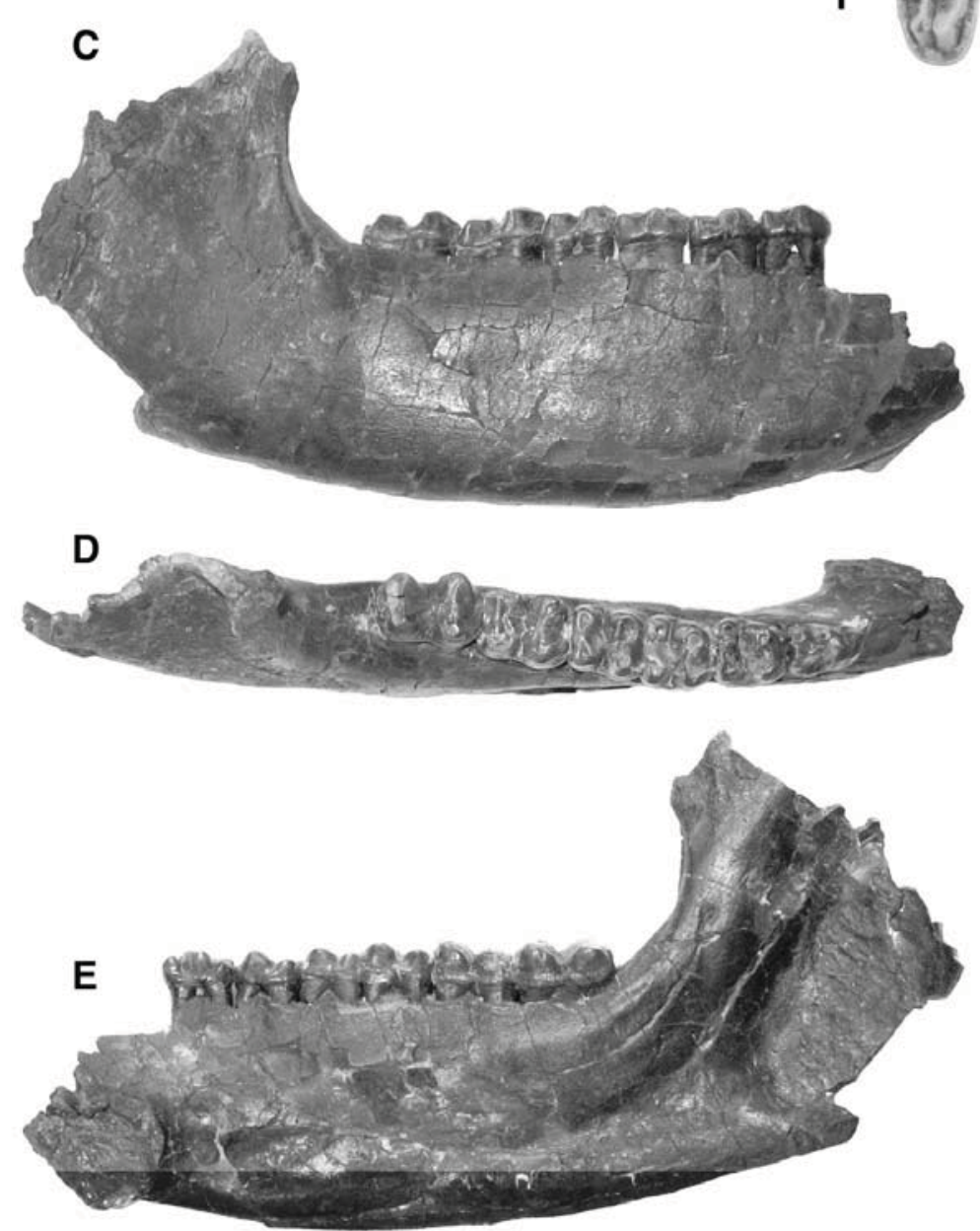

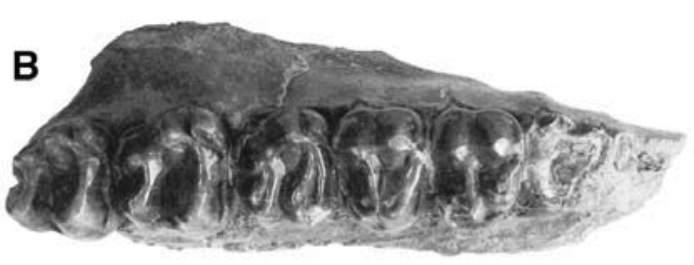

$\mathbf{J}$

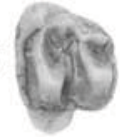

$\mathbf{K}$

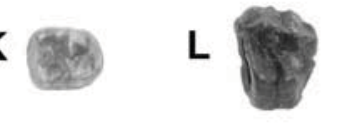

H

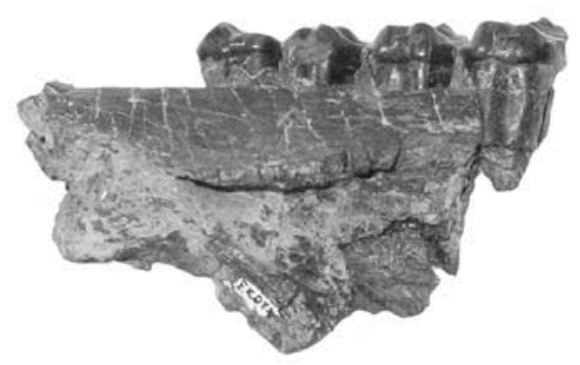

G
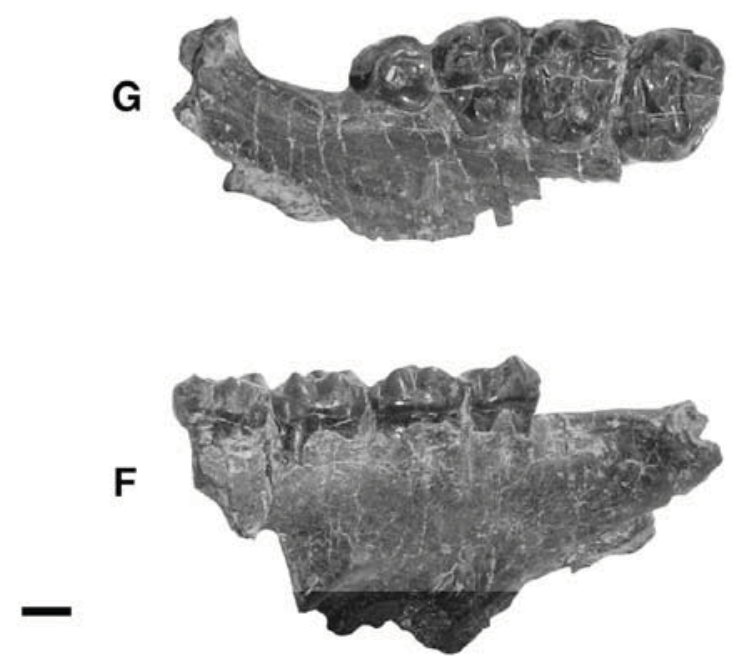

FIGURE 3. Tooth remains of Protapirus bavaricus, P. aginensis, and P. douvillei. A, left maxilla of P. bavaricus from Rüfi bei Schänis (PIMUZA/V79), labial view; $\mathbf{B}$, same in occlusal view; $\mathbf{C}$, right mandible of $P$. bavaricus from Ebnat-Kappel (EKO-T1), labial view; D, same in occlusal view; $\mathbf{E}$, same in lingual view; $\mathbf{F}$, left maxilla of $P$. bavaricus from Ebnat-Kappel (EKO-T4), labial view; $\mathbf{G}$, same in occlusal view; $\mathbf{H}$, same in lingual view; I, left P4 of $P$. aginensis from La Milloque (NMB-Lm421), occlusal view; J, left M2 of $P$. aginensis from La Milloque (NMB-Lm1404), occlusal view; $\mathbf{K}$, left $\mathrm{p} 4$ of $P$. aginensis from La Milloque (NMB-Lm420), occlusal view; L, left P4 of $P$. douvillei from Buchberg 6 (PIMUZ-A/V690), occlusal view. Scale bar equals $1 \mathrm{~cm}$.

protolophid is concave on $\mathrm{m} 1$ but straight on $\mathrm{m} 2$ and $\mathrm{m} 3$, and the hypolophid is straight. There is a short and slightly developed anterior cingulid on $\mathrm{m} 2$ (character not visible on $\mathrm{m} 1$ and $\mathrm{m} 3$ ), a short posterior cingulid slightly developed on $\mathrm{m} 1$ but developed on $\mathrm{m} 2$ and $\mathrm{m} 3$, a short labial cingulid at the level of the median valley, slightly developed on $\mathrm{m} 1$ but weak on $\mathrm{m} 2$ and $\mathrm{m} 3$ but no lingual cingulid.

\section{Discussion}

The comparison of the maxilla of Rüfi bei Schänis with the two fragmentary maxillae of Ebnat-Kappel indicates that the three specimens share the same diagnostic characters: the premolars are not molarized; the protocone and hypocone are strongly fused, closing the median valley; and the protoloph and metaloph 
are lingually convergent and not subparallel. These specimens also differ from the type species Protapirus aginensis of La Milloque (see further descriptions) with less developed parastyles, cingula, and postfossae, the absence of a lingual pseudofossa, and consequently smaller general size. All of these reasons support the assignment of the specimens from Ebnat-Kappel and Rüfi bei Schänis to Protapirus bavaricus.

Cerdeño and Ginsburg (1988) ascribed the left maxilla from Rüfi bei Schänis to the species Protapirus bavaricus. According to these authors, the two late Oligocene species of Protapirus, $P$. bavaricus and $P$. aginensis, can be distinguished by the relative space between the protocone and the metacone; Protapirus bavaricus is a transitional species between $P$. priscus and $P$. aginensis, with $\mathrm{P} 3$ and $\mathrm{P} 4$ protocones and hypocones more fused in $P$. bavaricus than in $P$. aginensis. Nevertheless, this distinction is not always evident, and the respective diagnoses need to be specified.

\section{PROTAPIRUS AGINENSIS (Richard, 1938) (Fig. 3; Table 3)}

Type Locality_La Milloque, France (late Oligocene, MP29). Synonymy - See Cerdeño and Ginsburg (1988:5) for recent synonymy list.

Distribution-Late Oligocene of France (Schaub, 1928; Richard, 1938, 1948; Cerdeño and Ginsburg, 1988) (Table 2).

Emended Diagnosis-Similar in size to Protapirus bavaricus; less fused protocone and metacone on P3 and P4; less broad P2; stockier anterior part of the lower premolars (translation of Cerdeño and Ginsburg, 1988:5); well-developed postfossa and presence of a lingual pseudofossa on upper premolars.

Referred Specimens - La Milloque (France, MP29): type locality of the species; left p4 (NMB-Lm420), right P4 (NMB-Lm421), two left M2s (NMB-Lm422, NMB-Lm1404).

\section{Description}

Upper Dentition-P4 is subrectangular, not molarized, with oblique ectoloph. The oblique protoloph and straight metaloph are lingually convergent, and the protocone and metacone are fused, lingually closing the median valley. There is a developed parastyle, a continuous and developed anterior cingulum (from the parastyle to the middle of the protocone), a continuous and well-developed posterior cingulum (from the middle of the metacone to the middle of the hypocone), an almost continuous and developed labial cingulum only lacking at the level of the paracone, and a short and developed lingual cingulum closing a small pseudofossa. The postfossa is well developed. M2 is trapezoidal, with strongly oblique ectoloph. The reduced and oblique metaloph and straight protoloph are lingually divergent, and the protocone and hypocone are unfused and well separated, allowing the lingual opening of the median valley. There is a strong parastyle, a continuous and developed anterior cingulum (from the parastyle to the middle of the protocone), a continuous and slightly developed posterior cingulum (from the middle of the metacone to the middle of the hypocone), a subhorizontal and slightly developed posterior labial cingulum around the metacone and joining the posterior cingulum, and a short and slightly developed lingual cingulum closing a pseudofossa. The postfossa is slightly developed.

Lower Dentition-p4 is not molarized, with an isolated entoconid (conical entoconid and hypoconid not fused in a hypolophid), and a wider talonid than trigonid. The paracristid is developed, and the protolophid is slightly concave, with two subvertical crests on its posterior side. The metastylid is developed in an accessory cusp. There is a short and slightly developed anterior cingulid, a short, oblique, and developed posterior cingulid, a short and weak labial cingulid at the level of the median valley, but no lingual cingulid.

\section{Discussion}

The tapir fossils of La Milloque are described as the type species Protapirus aginensis (Oettingen-Spielberg, 1952; Cerdeño and Ginsburg, 1988). The characters of the upper dentition, such as the unmolarized premolars with fused protocone and hypocone and lingually convergent protoloph and metaloph closing the median valley, support assignment to the genus Protapirus. The attribution to Protapirus aginensis is attested by welldeveloped parastyles, cingula, and postfossae, the presence of a lingual pseudofossa, and a larger size than $P$. bavaricus.

\section{PROTAPIRUS DOUVILLEI (Filhol, 1885)}

(Fig. 3; Table 3)

Type Locality-Saint-Gérand-le-Puy, France (early Miocene, MN2a).

Synonymy-See Cerdeño and Ginsburg (1988:8-9) for recent synonymy list.

Distribution-Early Miocene of France (Filhol, 1885; Gaudry, 1897; Depéret and Douxami, 1902; Roman, 1919; Schaub, 1928; Viret, 1929; Cerdeño and Ginsburg, 1988; Heissig, 1999a) and Switzerland (this study) (Table 2).

Emended Diagnosis-Larger than Protapirus priscus; more separated protocone and metacone on P3 and P4 but as fused as in Protapirus priscus; no lingual cingulum and highly reduced labial cingula on the upper premolars; narrow $\mathrm{P} 2$ and $\mathrm{P} 3$; thinned protoloph on P2 (translation of Cerdeño and Ginsburg, 1988:9); developed postfossa and absence of lingual pseudofossa on upper premolars.

Referred Specimens-Buchberg 6 (Switzerland, MN4): left P4 (PIMUZ-A/V690).

\section{Description}

Upper Dentition-P4 is subrectangular, not molarized, with oblique ectoloph. The oblique protoloph and straight metaloph are lingually convergent, and the protocone and hypocone are fused, closing the median valley. There is a weak parastyle, a continuous and developed anterior cingulum (from the parastyle to the middle of the protocone), a continuous and slightly developed posterior cingulum (from the middle of the metacone to the front of the hypocone), but no labial nor lingual cingula. The postfossa is developed.

\section{Discussion}

This upper premolar shares the characteristics of the genus Protapirus: unmolarized premolar with lingually convergent protoloph and metaloph and fused protocone and hypocone closing the median valley. Moreover, the absence of lingual and labial cingula allows its attribution to the species Protapirus douvillei. Further observations confirm the differentiation of this specimen from the other species Protapirus bavaricus and Protapirus aginensis (such as a better-developed postfossa than on P. bavaricus, but not as well-developed as on $P$. aginensis, and less developed anterior and posterior cingula than on $P$. aginensis).

\section{Genus PARATAPIRUS Depéret and Douxami, 1902}

Neotype Species-Paratapirus helvetius (Meyer, 1867) from Haslen, Switzerland (late Oligocene, MP28-30).

Other Species Referred to the Genus-P. intermedius (Filhol, 1885).

Distribution-Late Oligocene to early Miocene of Europe.

Diagnosis-Medium-sized Tapiridae; square, molarized P2; rectangular P3 and P4 with subparallel and separated protoloph and metaloph and unfused protocone and hypocone, allowing the lingual opening of the median valley (translation of Cerdeño and Ginsburg 1988:10). 
PARATAPIRUS HELVETIUS (Meyer, 1867)

(Fig. 4; Table 3)

Neotype Locality-Haslen, Switzerland (late Oligocene, MP28-30).

Synonymy - See Cerdeño and Ginsburg (1988:10) for recent synonymy list.

Distribution-Late Oligocene of Switzerland (Meyer, 1867; Depéret and Douxami, 1902; Schaub, 1928; Viret, 1929, 1958; Cerdeño and Ginsburg, 1988) (Table 2).

Diagnosis-Paratapirus with primitive characters; straight and parallel protoloph and metaloph on P3 and P4 (translation of Cerdeño and Ginsburg, 1988:10).

Referred Specimens-Haslen (Switzerland, MP28-30): skull with complete left and right tooth row (NMSG-P1500), right mandible with m1-m3 (NMSG-P1501).

\section{Description}

Skull-The partially complete skull lacks the occipital region and the posterior part of the zygomatic arches and bears the complete left and right tooth rows, with broken left P4-M3, left and right $\mathrm{I} 1-\mathrm{I} 2$, right $\mathrm{I} 3$, and left and right $\mathrm{C}$. In lateral view, the anterior part of the nasal bones reaches the level of P1, the bottom of the nasal notch is situated between M1 and M2, the anterior part of the orbitotemporal fossa reaches the level of M1, the suborbital process of the orbitotemporal fossa is situated between M2 and M3, and the postorbital process is situated posterior to M3. In vertical view, the nasal bones form an acute anterior point, and the intermaxiliar bones are not drawn aside. In basal view, the intermaxiliar bones are fused anteriorly, as well as fused posteriorly before $\mathrm{P} 1$, with a small and lengthened incisor notch (from the middle of $\mathrm{I} 3$ to the middle of the C-P1 diastema). There is at least one pair of palatine foramina situated 8 $\mathrm{mm}$ anteriorly to the palatine notch, which is situated at the level of M2.

Upper Dentition-I1, I2, and I3 increase in size from I1 to I3, with a well-developed I3 that functionally substitutes for the canine. $\mathrm{C}$ is small, with a rounded section. P1 is elongated and triangular, not molarized, with a straight ectoloph. The paracone and metacone are close, and there is a lingual fossa with slightly raised internal wall bearing the protocone and hypocone. The parastyle is weak, and there is a weak but true metastyle. There is a slightly developed posterior cingulum and a slightly developed lingual cingulum. P2 is subquadratic, not molarized, with a slightly oblique ectoloph. The slightly reduced and oblique protoloph and straight metaloph are lingually convergent, and the protocone and hypocone are fused, closing the median valley. The parastyle is weak. There is a continuous and weak anterior cingulum (from the parastyle to the middle of the protocone), a continuous and developed posterior cingulum (from the metacone to the middle of the hypocone), a continuous and slightly developed lingual cingulum, but no labial cingulum. The postfossa is undeveloped. P3 and P4 are subrectangular, not molarized, with straight ectoloph. The protoloph and metaloph are subparallel and of same length, and the protocone and hypocone are fused, closing the median valley. The parastyle is weak. There is a continuous and weak anterior cingulum (from the parastyle to the middle of the protocone), a continuous and developed posterior cingulum (from the metacone to the middle of the hypocone), a short lingual cingulum slightly developed on P3 but weak on $\mathrm{P} 4$, but no labial cingulum. The postfossa is undeveloped. M1, M2, and M3 are trapezoidal, with oblique ectoloph. The highly reduced and oblique metaloph and straight protoloph are lingually divergent, and the protocone and hypocone are well separated, allowing the lingual opening of the median valley. The parastyle is weak on M1 but well developed on M2 and M3. There is a continuous and slightly developed anterior cingulum (from the parastyle to the middle of the metacone), a continu- ous and slightly developed posterior cingulum (from the metacone to the middle of the hypocone), a short and weak lingual cingulum, but no labial cingulum. The postfossa is slightly developed.

Mandible - The fragmentary right mandible bears the $\mathrm{m} 1-\mathrm{m} 3$ that are broken in two and lack the labial part of each one. The $\mathrm{m} 1$ is only a fragment bearing the protoconid. The mandible is not yet fully prepared. No morphological characters can be observed because of the bad preservation of this mandible, but biometrical measurements have been done.

\section{Discussion}

The $\mathrm{P} 2$ is molarized and square, whereas $\mathrm{P} 3$ and $\mathrm{P} 4$ are rectangular with parallel protoloph and metaloph, which characterizes the genus Paratapirus. The assignment to Paratapirus helvetius is supported by the primitive character of fused protocone and hypocone closing the median valley on the premolars. This skull has already been ascribed to the species Paratapirus helvetius by Schaub (1928) and Cerdeño and Ginsburg (1988). Meyer (1867) described a skull and a mandible from Othmarsingen (late Oligocene, Switzerland) as the type species Paratapirus helvetius. Unfortunately, this skull was missing the cheek teeth-broken at the level of the roots - and later the mandible disappeared from the collections. After the discovery of the tapir skull from Haslen with a complete tooth row and a right mandible, Schaub (1928) designated them as the neotype of Paratapirus helvetius.

\section{PARATAPIRUS INTERMEDIUS (Filhol, 1885)}

(Fig. 4; Table 3)

Type Locality-Selles-sur-Cher, France (early Miocene, MN2b).

Synonymy-See Cerdeño and Ginsburg (1988:11) for recent synonymy list.

Distribution-Early Miocene of France, Germany, and Switzerland (Filhol, 1885; Zittel, 1894; Depéret and Douxami, 1902; Stehlin, 1909; Schlosser, 1910; Schaub, 1928; Viret, 1929; von Koenigswald, 1930; Ginsburg, 1980; Ginsburg and Hugueney, 1980; Ginsburg et al., 1982; Cerdeño and Ginsburg, 1988; Heissig, 1999a; this study) (Table 2).

Diagnosis-Paratapirus with well-molarized P2; subrectangular P2, P3, and P4; P3 and P4 slightly longer than in Paratapirus helvetius; slightly lingually convergent protoloph and metaloph on P3; parallel or slightly convergent protoloph and metaloph on P4 (translation of Cerdeño and Ginsburg, 1988:11).

Referred Specimens-Greit, Höhronen (Switzerland, MN1): fragmentary right mandible with $\mathrm{m} 1-\mathrm{m} 2$ (PIMUZ-A/V0061), fragmentary left mandible with p2 broken and p3 (PIMUZA/V0063), fragmentary left mandible with p3-p4 (PIMUZA/V64), fragmentary right mandible (cast) with p3-p4 (PIMUZ$\mathrm{A} / \mathrm{V} 0065)$, incomplete mandible with left $\mathrm{c}-\mathrm{m} 3$ and right p2-m3 (PIMUZ-A/V148), fragmentary left maxilla with M1-M2 (PIMUZ-A/V64); Sparen am Höhronen (Switzerland, MN1) fragmentary right mandible with m1-m3 (PIMUZ-A/V0062); Brüttelen 1 (Switzerland, MN3a): fragmentary left mandible with broken m2-m3 (NMBE-5014554), fragmentary left tibia (NMBE-5014553); Saulcet (France, MN1): fragmentary left subadult mandible with p3-m3 (NMB-Sau2282).

\section{Description}

Upper Dentition-M1 and M2 are trapezoidal, with oblique ectoloph on M1 and strongly oblique on M2. The reduced and oblique metaloph and straight protoloph are lingually divergent, and the protocone and hypocone are unfused and well separated, allowing the lingual opening of the median valley. The parastyle is well developed. There is a continuous and developed anterior cingulum (from the parastyle to the middle of the protocone), 


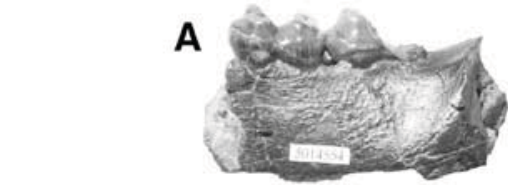

B
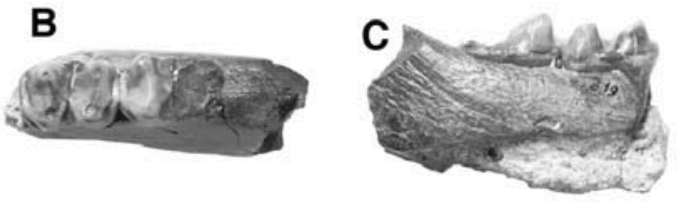

E
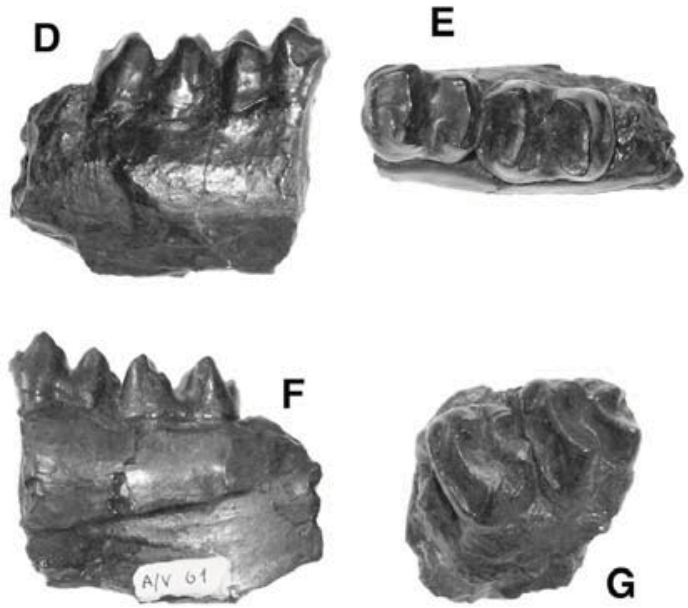
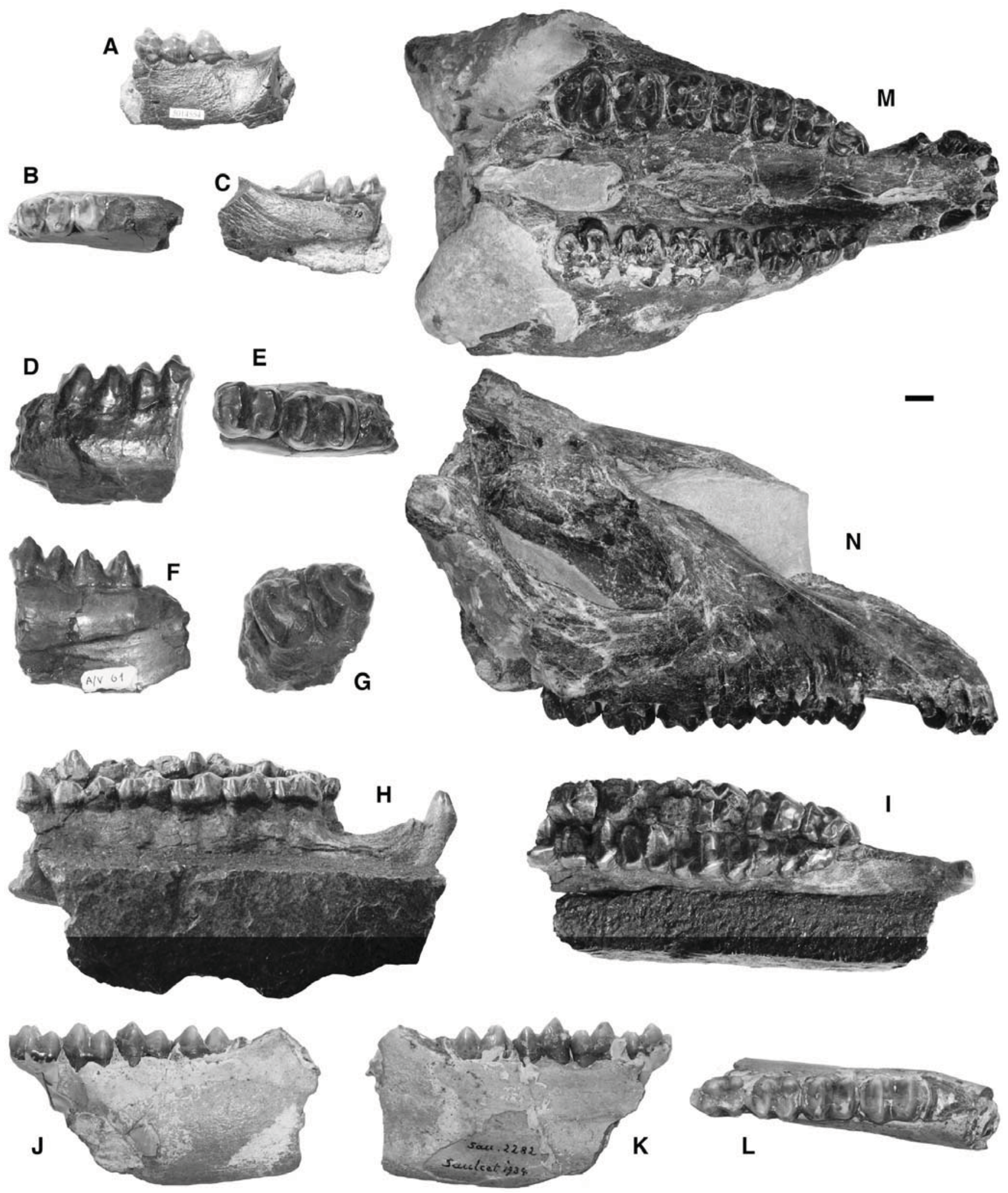

FIGURE 4. Tooth remains of Paratapirus intermedius and P. helvetius. A, left mandible of P. intermedius from Brüttelen 1 (NMBE-5014554), labial view; $\mathbf{B}$, same in occlusal view; $\mathbf{C}$, same in lingual view; $\mathbf{D}$, right mandible of $P$. intermedius from Höhronen (PIMUZ-A/V0061), labial view; $\mathbf{E}$, same in occlusal view; $\mathbf{F}$, same in lingual view; $\mathbf{G}$, left maxilla of $P$. intermedius from Höhronen (PIMUZ-A/V64), occlusal view; $\mathbf{H}$, mandible of $P$. intermedius from Höhronen (PIMUZ-A/V148), lateral view; I, same in occlusal view; J, subadult left mandible of $P$. intermedius from Saulcet (NMB-Sau2282), labial view; K, same in lingual view; $\mathbf{L}$, same in occlusal view; $\mathbf{M}$, skull of $P$. helvetius from Haslen (NMSG-P1500), basal view; N, same in lateral view. Scale bar equals $1 \mathrm{~cm}$. 
a short and slightly developed lingual posterior cingulum on M2 (not visible on M1), a slightly developed posterior labial cingulum around the metacone subhorizontal on M1 and oblique on M2, and a short and slightly developed lingual cingulum. The postfossa is undeveloped on M1 but slightly developed on M2.

Lower Dentition-p2 is not molarized, with an isolated entoconid (conical entoconid and hypoconid not fused in a hypolophid). The paracristid is well developed and elongated in a paralophid. The posterior cingulid is not visible. There is a short and weak labial cingulid at the level of the median valley, but no anterior nor lingual cingulids. p3 and p4 are not molarized, with an isolated entoconid (conical entoconid and hypoconid not fused in a hypolophid), and a wider talonid than trigonid. The paracristid is developed. The protolophid is concave on $\mathrm{p} 3$ but slightly concave on $\mathrm{p} 4$, and there are three subvertical crests on its posterior side on $\mathrm{p} 3$ but only two on $\mathrm{p} 4$. The metastylid is developed. There is a short and weak anterior cingulid, a short and slightly developed posterior cingulid, a short and weak labial cingulid at the level of the median valley, but no lingual cingulid. $\mathrm{m} 1$, $\mathrm{m} 2$, and $\mathrm{m} 3$ have a wider trigonid than talonid. The paracristid is slightly developed on $\mathrm{m} 1$ and $\mathrm{m} 2$ but developed on $\mathrm{m} 3$. The protolophid is slightly concave on $\mathrm{m} 1$ but straight on $\mathrm{m} 2$ and $\mathrm{m} 3$, with two subvertical crests on its posterior side. The metastylid is slightly developed. The hypolophid is straight, but without vertical crests on its posterior side. There is a short and weak anterior cingulid on $\mathrm{m} 1$ but slightly developed on $\mathrm{m} 2$ and $\mathrm{m} 3$ around the protoconid, a short and slightly developed posterior cingulid on $\mathrm{m} 1$ and $\mathrm{m} 3$ but developed on $\mathrm{m} 2$, but no labial nor lingual cingulids.

\section{Discussion}

The determination of a tapir species with only lower dentitions and upper molars is highly problematic. The tapir species and genera are determined with respect to the upper premolars, because there are no distinguishing characters present on the lower dentition. No remarkable morphological characters could be observed on the specimens from Höhronen (Greit and Sparen), Brüttelen 1, and Saulcet, except for the very large size of the individuals. The genera Protapirus and Eotapirus are rather small tapirids and only the genera Paratapirus and Tapirus can reach such dimensions (see Table 3 for the dimensions of Paratapirus intermedius). The genus Tapirus can be excluded with certainty because of biostratigraphic aspects, because this genus appeared in Europe only in MN9. Studer (1895) described the specimen of Brüttelen 1 as Tapirus helvetius-synonym of Paratapirus helvetius. We disagree with him because of the larger size of our specimens (around $8 \%$ larger than the average size of Paratapirus helvetius), which have the same dimensions as the specimens from Höhronen and Saulcet (Table 3). According to Schaub (1928), the specimens from Höhronen, Brüttelen 1, and Saulcet are attributed to Paratapirus intermedius, which is the derived form of the small primitive Paratapirus helvetius.

\section{EOTAPIRUS Cerdeño and Ginsburg, 1988}

Type Species-Eotapirus broennimanni (Schaub and Hürzeler, 1948).

Type Locality-Pyrimont-Challonges, France (Aquitanian, MN1).

Other Species Referred to the Genus- - . ruber Cerdeño and Ginsburg, 1988.

Distribution-Oligocene to early Miocene of Europe.

Diagnosis-Small-sized Tapiridae; triangular P2 with weakly developed protoloph; subquadratic and highly molarized P3 and P4 with well-separated protocone and hypocone (translation of Cerdeño and Ginsburg, 1988:14).

EOTAPIRUS BROENNIMANNI (Schaub and Hürzeler, 1948) (Fig. 5; Table 3)
Type Locality-Pyrimont-Challonges, France (early Miocene, MN1).

Synonymy—See Cerdeño and Ginsburg (1988:14) for recent synonymy list.

Distribution-Early Miocene of France and Switzerland (Depéret and Douxami, 1902; Viret and Hürzeler, 1937; Schaub and Hürzeler, 1948; Cerdeño and Ginsburg, 1988; Heissig, 1999a) (Table 2).

Diagnosis-Small-sized Tapiridae; triangular P2 with weakly developed protoloph; subquadratic and highly molarized P3 and P4 with well-separated protocone and hypocone (translation of Cerdeño and Ginsburg, 1988:14).

Referred Specimens-Wischberg (Switzerland, MN1): juvenile skull with left P1-M1 and right P1-DP4 (NMB-As7), fragmentary left juvenile mandible with dp3-dp4 (NMB-As7), fragmentary right juvenile mandible with $\mathrm{m} 1$ (NMB-As7), fragmentary right mandible with p2-p4 (NMBE-D3395), left I1 (NMBE-D3394); Benken (MN3-4?): right P2 (PIMUZA/V1781), left M1 (PIMUZ-A/V1782), left m1 (PIMUZA/V1782), left m3 (PIMUZ-A/V1782).

\section{Description}

Upper Deciduous Dentition-DP4 is subquadratic, well molarized, with oblique ectoloph. The slightly reduced but straight metaloph is parallel to the straight protoloph, and the protocone and hypocone are unfused and well separated, allowing the lingual opening of the median valley. The parastyle is well developed. There is a continuous and slightly developed anterior cingulum (from the parastyle to the middle of the protocone), a continuous and weak posterior cingulum (from the metacone to the middle of the hypocone), a subhorizontal and developed posterior labial cingulum around the metacone and joining the posterior cingulum, and a short and weak lingual cingulum. The postfossa is undeveloped.

Upper Adult Dentition-P1 is elongated and triangular, not molarized, with straight ectoloph. The paracone and metacone are close, and there is a lingual fossa with slightly raised internal wall bearing the protocone and hypocone. The parastyle is slightly developed. There is a weak but true metastyle, but no cingula. P2 is subtriangular, almost molarized, with straight ectoloph. The reduced and slightly oblique protoloph and straight metaloph are lingually convergent, and the protocone and hypocone are unfused and well separated, allowing the lingual opening of the median valley. The parastyle is well developed. There is a continuous and weak anterior cingulum (from the parastyle to the middle of the protocone), a continuous and slightly developed posterior cingulum (from the metacone to the middle of the hypocone), a subhorizontal and slightly developed posterior labial cingulum around the metacone and joining the posterior cingulum, and a short and weak lingual cingulum. The postfossa is undeveloped. P3 is subquadratic, well molarized, with slightly oblique ectoloph. The protoloph and metaloph are subparallel and of same length, and the protocone and metacone are unfused and well separated, allowing the lingual opening of the median valley. The parastyle is well developed. There is a continuous and slightly developed anterior cingulum (from the parastyle to the middle of the protocone), a continuous and slightly developed posterior cingulum (from the metacone to the middle of the hypocone), a subhorizontal and developed posterior labial cingulum around the metacone and joining the posterior cingulum, but no lingual cingulum. The postfossa is undeveloped. M1 is trapezoidal, with oblique ectoloph. The highly reduced but straight metaloph is parallel to the straight protoloph, and the protocone and hypocone are unfused and well separated, allowing the lingual opening of the median valley. The parastyle is strong. There is a continuous and slightly developed anterior cingulum (from the parastyle to the middle of the protocone), a 

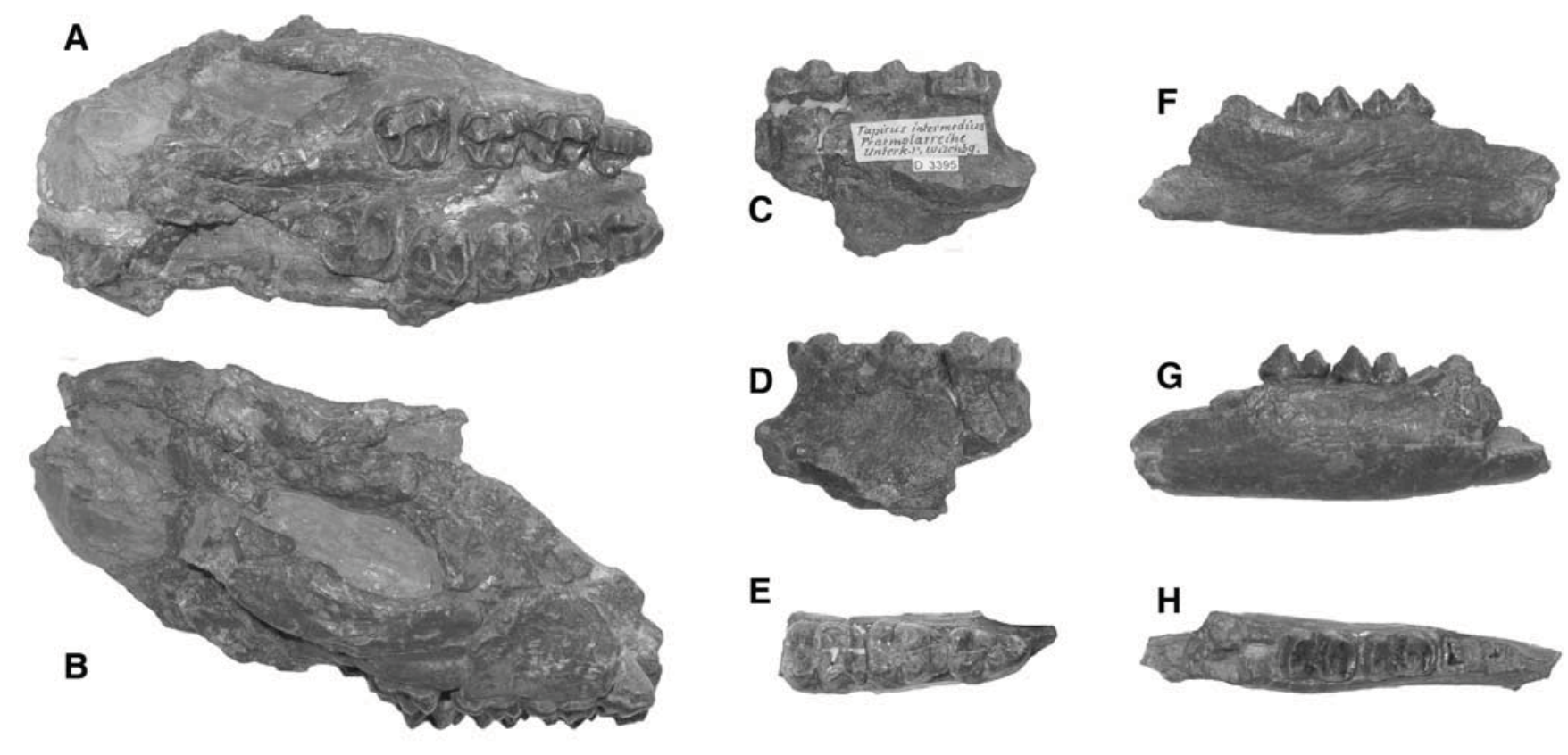

E
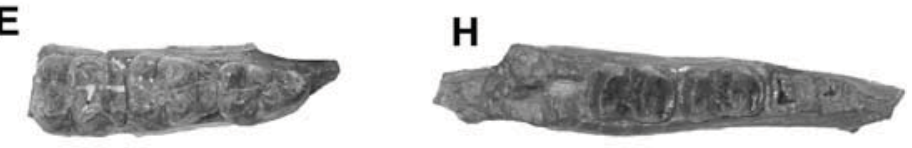

I

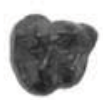

$\mathbf{J}$

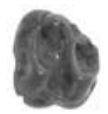

$\mathbf{K}$

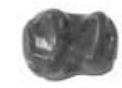

$\mathbf{L}$

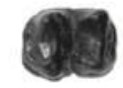

FIGURE 5. Tooth remains of Eotapirus broennimanni. A, juvenile skull from Wischberg (NMB-As7), occlusal view; $\mathbf{B}$, same in lateral view; C, right mandible from Wischberg (NMBE-D3395), labial view; D, same in lingual view; E, same in occlusal view; $\mathbf{F}$, juvenile left mandible from Wischberg (NMB-As7), lingual view; G, same in labial view; H, same in occlusal view; I, right P2 from Benken (PIMUZ-A/V1781), occlusal view; J, left M1 from Benken (PIMUZ-A/V1782), occlusal view; K, left m1 from Benken (PIMUZ-A/V1782), occlusal view; L, left m3 from Benken (PIMUZ-A/V1782), occlusal view. Scale bar equals $1 \mathrm{~cm}$.

discontinuous and weak posterior cingulum forming small acute waves, a subhorizontal and developed posterior labial cingulum around the metacone, and a short and weak lingual cingulum closing a pseudofossa. The postfossa is slightly developed.

Lower Deciduous Dentition- $\mathrm{dp} 3$ and dp4 are molarized, with a wider talonid than trigonid on $\mathrm{dp} 3$ but of same size on $\mathrm{dp} 4$. The paracristid is developed. The protolophid is concave on dp3 but slightly concave on dp4, with three subvertical crests on its posterior side. The hypolophid is concave on dp3 but slightly concave on dp4, with four short subvertical crests on its posterior side on dp3, but no one on dp4. The metastylid is slightly developed. There is a slightly developed anterior cingulid around the protoconid, a short and developed posterior cingulid, a short and weak labial cingulid at the level of the median valley, but no lingual cingulid.

Lower Adult Dentition - $\mathrm{p} 2$ is not molarized, with an isolated entoconid (conical entoconid and hypoconid not fused in a hypolophid). The paracristid is well developed and elongated in a paralophid. The posterior cingulid is not visible, and there is no anterior, labial, nor lingual cingulids. p3 and p4 are not molarized, with an isolated entoconid (conical entoconid and hypoconid not fused in a hypolophid) and a wider talonid than trigonid. The paracristid is developed. The protolophid is concave on $\mathrm{p} 3$ but slightly concave on $\mathrm{p} 4$, but subvertical crests and metastylid are not visible (worn teeth). The anterior cingulid is not visible. There is a short and slightly developed posterior cingulid on $\mathrm{p} 4$ (not visible on $\mathrm{p} 3$ ), but no labial nor lingual cingulids. $\mathrm{m} 1$ and $\mathrm{m} 3$ have a wider trigonid than talonid. The paracristid is slightly developed on $\mathrm{m} 1$ but developed on $\mathrm{m} 3$. The protolophid is slightly concave on $\mathrm{m} 1$ but straight on $\mathrm{m} 3$, with two subvertical crests on its posterior side. The metastylid is slightly developed. The hypolophid is straight, with two short subvertical crests on its posterior side. There is a slightly developed anterior cingulid around the protoconid on $\mathrm{m} 1$ but weak and short on $\mathrm{m} 3$, a short and slightly developed posterior cingulid, but no labial nor lingual cingulids.

\section{Discussion}

Cerdeño and Ginsburg (1988) assigned the specimen from Wischberg to the new genus Eotapirus and the species E. broennimanni based on the characters of the upper dentition. The $\mathrm{P} 2$ is triangular with a reduced protoloph lingually convergent to the metaloph, whereas P3 and P4 are well molarized and subquadratic with subparallel protoloph and metaloph. Furthermore, the protocone and metacone of the premolars are unfused and well separated and do not close the lingual part of the median valley. The specimen from Benken shares the same characteristics and no morphological or biometrical differentiations can be observed by comparing both P2s. The specimens from Wischberg and Benken are assigned with confidence to E. broennimanni.

\section{Family TAPIRIDAE Gray, 1821}

Tapiridae indet-Aarwangen (MP27): left Mx (NMB-AW35); Paudex (MP29): left Mx (MHNG-v4108); Würenlos (MN3): fragmentary right mandible with p3-p4 (PIMUZ-A/V0075).

Description-The isolated upper molar from Aarwangen is worn and incomplete, and bears only the lingual part of the 
protoloph (protocone) with a slightly developed anterior cingulum and a short and slightly developed lingual cingulum. The isolated upper molar from Paudex is worn and incomplete and bears just the labial side of the tooth with a well-developed anterior cingulum and a weak posterior labial cingulum. The fragmentary mandible from Würenlos bears incomplete p3 (broken anterior part) and $\mathrm{p} 4$ (broken posterior part); the p3 is not molarized with an isolated entoconid and a short and slightly developed posterior cingulid and the $\mathrm{p} 4$ has a slightly concave protolophid and a short and weak anterior cingulid around the protoconid.

\section{Discussion}

These fossil remains are too incomplete to be identified beyond Tapiridae indet. Nevertheless, some characters of tapirids can be distinguished clearly on these tooth fragments, such as their bilophodont morphology. This allows their assignment to Tapiridae.

\section{DISCUSSION}

\section{Biostratigraphy}

The occurrences of early Oligocene to early Miocene European Tapiridae are illustrated in Figure 6 and complete references are given in Table 2. Protapirus priscus from the fillings of Möhren 19 and 20 (MP21, Germany) is the first well-dated record of Tapiridae in Europe (Heissig, 1978, 1999a). There is also an M3 described by Böhme (2001) as Protapirus bavaricus in Espenhain (MP22, Germany). However, according to the diagnostic characters of the species and the results of this paper, a species cannot be determined based only on lower teeth or upper molars, and this determination is therefore questionable. It would be more reliable to ascribe this tapir from Espenhain to Protapirus sp. Regarding Protapirus priscus and Eotapirus ruber from the Phosphorites du Quercy, these localities are very poorly documented and are not mentioned in the faunal list of Remy et al. (1987), who used only well-dated localities. These two species cannot be better dated than to the interval MP22 to MP28.

Originally described in Gaimersheim (MP27, Germany), the biostratigraphic range of Protapirus bavaricus can be extended to the Mammal Biozone MP29 with the determinations of the Swiss specimens from Ebnat-Kappel and Rüfi bei Schänis dated to MP28 and MP29 (base of the biozone), respectively. To date, Protapirus aginensis has only been described in La Milloque (MP29, France). According to the anagenetic lineage of Protapirus of Cerdeño and Ginsburg (1988), the speciation time from $P$. bavaricus to $P$. aginensis could be dated to around MP29. The last representative species of the genus-Protapirus douville $i$ - occurs mainly in the Aquitanian of France (Saint-Gérandle-Puy, Fontcaude, Pauhliac, Montaigu). Regarding the record of Protapirus douvillei in Buchberg 6 (Switzerland), its geographic distribution is extended eastwards and its biostratigraphy ranges until the end of the Mammal Biozone MN4.

The only Spanish species Protapirus cetinensis has been described in Cetina de Aragón and Valquemado (MN2a, Spain). This taxon, very close to $P$. aginensis, seems to have been derived from $P$. bavaricus during the late Oligocene (Cerdeño and Ginsburg, 1988). It supports a sporadic faunal migration between France and the Iberian Peninsula followed by regional endemism, as illustrated by the Spanish evolution of Anchitherium during the middle Miocene or Hipparion during the Pliocene (e.g., Costeur, 2009).

Paratapirus helvetius is only known to date in the latest Oligocene (MP28-30) of Switzerland (Haslen and Othmarsingen). Paratapirus intermedius is commonly described in the early Miocene (MN1 to MN4) of France (Saulcet, Selles-sur-Cher, Laugnac, Brux, Faluns of Touraine and Anjou) and Germany (Eggingen-Gemeindesteinbruch, Eggingen-Mittelhart 3, Hessler,

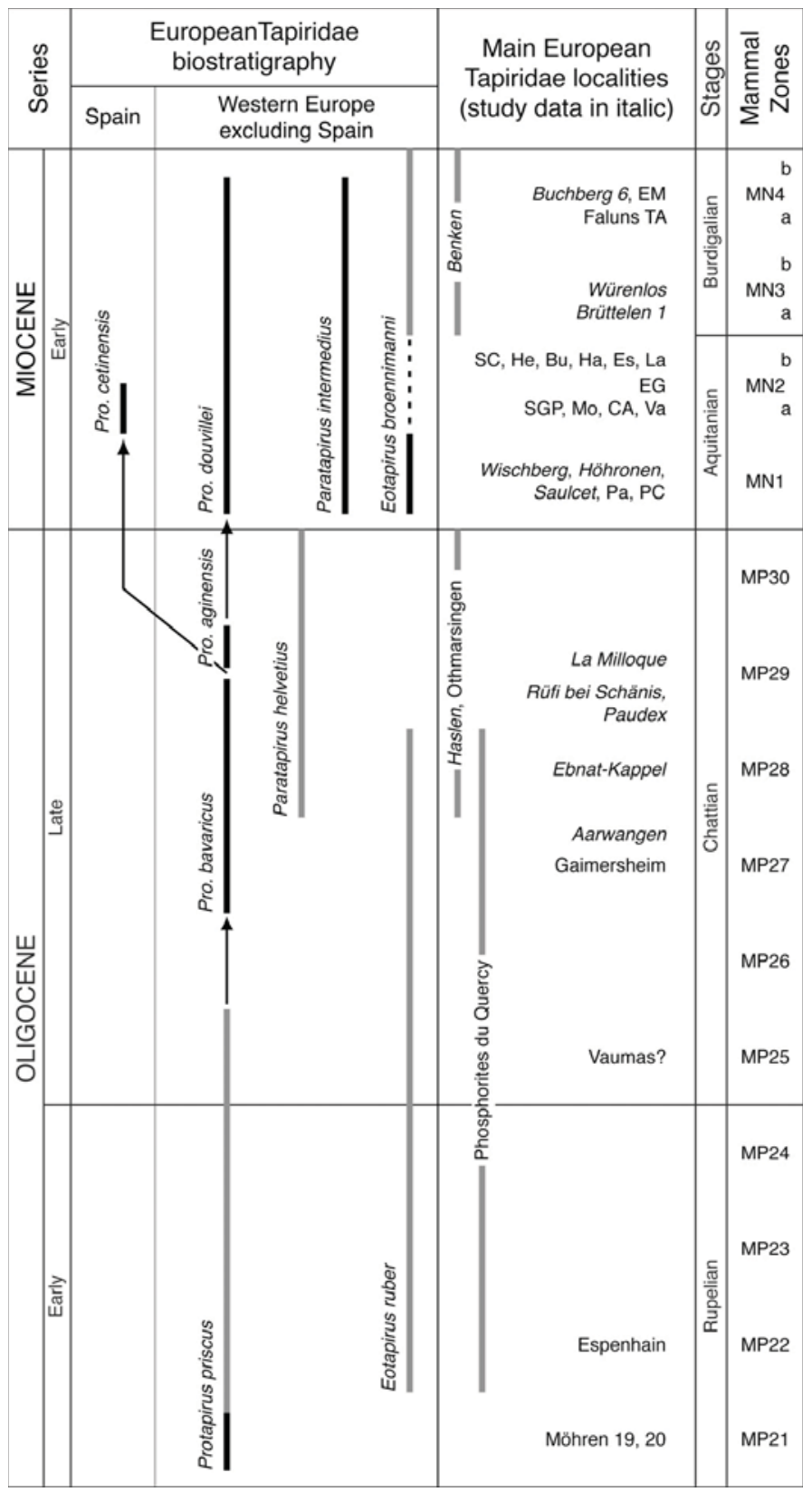

FIGURE 6. Biostratigraphic range of the European Tapiridae based upon the literature (see Table 2 for complete references) and the new data of this study. New locality data are in italics. Black lines: true occurrences; grey lines: poorly dated occurrences; dashed lines: uncertain occurrences; arrows: supposed speciations as stated in Cerdeño and Ginsburg (1988). The localities sampled in this paper are shown in italics. Abbreviations: Bu, Budenheim; CA, Cetina de Aragon; EG, EggingenGemeindesteinbruch; EM, Eggingen-Mittelhart 3; Es, Eselsberg; Faluns TA, Faluns of Touraine and Anjou; Ha, Haslach; He, Hessler; La, Laugnac; Mo, Montaigu; Pa, Paulhiac; PC, Pyrimont-Challonges; SC, Selles-sur-Cher; SGP, Saint-Gérand-le-Puy; Va, Valquemado.

Budenheim, Haslach, Eselsberg) and is also present in Switzerland with the specimens from Höhronen (MN1) and Brüttelen 1 (MN3a).

Eotapirus broennimanni was described in only two European localities dated to the Mammal Biozone MN1: PyrimontChallonges in France and Wischberg in Switzerland. A new 
occurrence of the species has been identified with the specimens of Benken (MN3-4?, Switzerland). Unfortunately, as this locality records reworked species from the late Oligocene and the early Miocene (see Geological Setting), the biostratigraphy of the tapir species E. broennimanni cannot be determined with precision nor extended without any doubt to the end of the Burdigalian.

\section{Paleoecology}

Extant tapirs are solitary animals primarily living in forested environments in a warm and wet climate with water proximity (Nowak, 1999). Their brachyodont bilophodont teeth are adapted for a folivorous, browsing diet helped by their short proboscis (Schoch, 1989; Eisenmann and Guérin, 1992). Fossil tapirids share the same anatomical characters as extant species and are inferred to have lived in the same kind of environment (Heissig, 1999a). This statement is reinforced by the ecologic comparison of the fauna associated with the Swiss tapir localities during the Oligocene-Miocene transition, which seems to indicate that they preferred forested and humid habitats (Fig. 7). The Suidae species are considered as forest forms because of their small body size (Fortelius et al., 1996). The anthracotheriid Microbunodon minimum was also a species of small size living in humid forested environments and feeding mostly on fruit (Lihoreau and Ducrocq, 2007). According to Becker (2003), most rhinocerotid species indicate rather humid forested environments (Eggysodon, Pleuroceros, Protaceratherium). The genus Diaceratherium generally denotes humid forested environments. Only $D$. lemanense seems to have preferred transitional zones between forest and grassland (Becker et al., 2009). The ecology of Ronzotherium romani indicates open, rather arid woodland environments (Uhlig, 1999; Becker et al., 2009). The ruminant Dremotherium quercyi lived in scattered forests whereas Palaeomeryx seems to have preferred open environments (Blondel, 1998). The European Oligocene anthracotheres (Anthracotherium, Elomeryx, Brachyodus) are usually affiliated to water (semi-aquatic); Anthracotherium was adapted to aquatic and swampy environments with its long and broad lateral digits (Lihoreau and Ducrocq, 2007).

\section{The Oligocene-Miocene Transition}

Climatic and environmental changes occurred in the late Oligocene and the early Miocene, leading to evolutionary responses by mammals. In the Chattian, the climate was quite stable with tropical to temperate influences (Becker, 2003). However, the Late Oligocene Warming (29 to $27 \mathrm{Ma}$; Vianey-Liaud, 1991; Zachos et al., 1997, 2001) was followed by a decrease in temperature and humidity leading to the Mi-1 Glaciation Event ( 22.9 Ma; Zachos et al., 1997, 2001). In the Aquitanian, the temperature increased again to reach the Miocene Climatic Optimum at the end of the early Miocene (17 to $15 \mathrm{Ma}$; Zachos et al., 2001; Böhme, 2003). The humidity also increased, leading to humid and swampy forested environments in the Burdigalian (Whybrow and Andrews, 2000). Later, in the Langhian (middle Miocene), the temperature began to slowly decrease again (Janis, 1989; Becker, 2003). At the scale of the Western Swiss Molasse Basin, these late Oligocene to early Miocene climatic and environmental changes are also well developed in the sedimentological record (e.g., Berger, 1990; Schlunegger et al., 2001; Becker, 2003), accentuated by the Alpine orogenesis.

Figure 8 illustrates the occurrences of early Oligocene to early Miocene European Tapiridae (according to Heissig, 1978, 1999a; Cerdeño and Ginsburg, 1988; this study), Rhinocerotoidea (Heissig, 1999b; Uhlig, 1999; Antoine et al., 2000; Becker, 2003, 2009; Becker et al., 2009; pers. observ.), Anthracotheriidae (Stehlin, 1910; Hellmund, 1991; Ginsburg and Chevrier, 2005; Lihoreau and Ducrocq, 2007; Lihoreau et al., 2009; pers. observ.), and

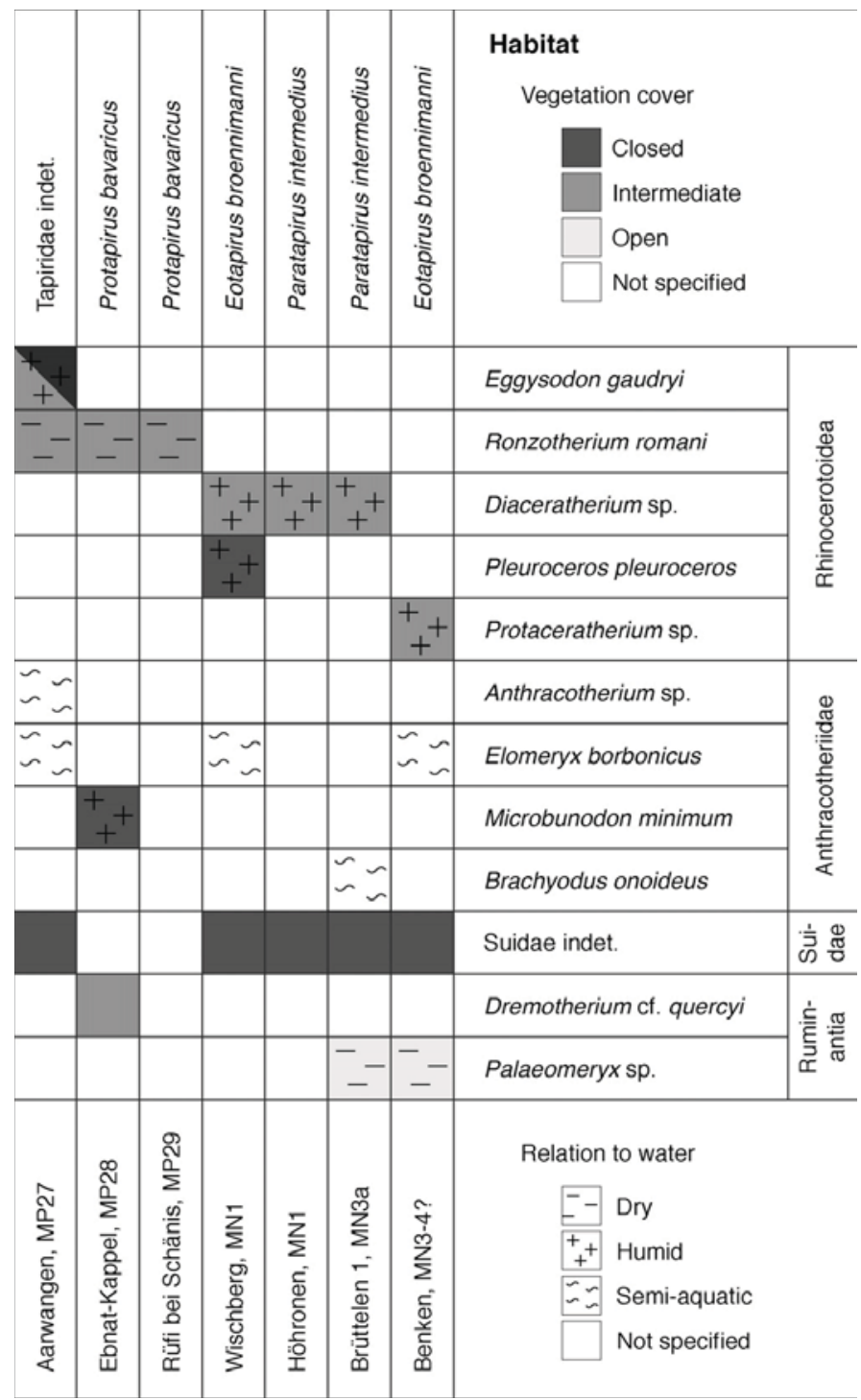

FIGURE 7. Associated fauna of the different tapirid localities of the Swiss Molasse Basin, with their environmental and ecological indications (faunal associations according to Hellmund, 1991; Fortelius et al., 1996; Becker, 2003; Ginsburg and Chevrier, 2005; B. Mennecart, pers. comm.; pers. data).

Suoidea (Hellmund, 1992; Fortelius et al., 1996). Three patterns of diversity and evolution can be observed: (1) the Tapiridae and the Suoidea were always represented by a weak abundance; they had a low diversity during the Oligocene and a diachronic diversification in the early Miocene, from MN1 for the Tapiridae and from MN(2)-3 for the Suoidea; (2) the Rhinocerotoidea were rather diverse during both time intervals, but a slight diversity increase occurred during the Oligocene-Miocene transition; and (3) the Anthracotheriidae were common during the Oligocene, but they were represented only by sporadic occurrences in the early Miocene and went extinct at the end of the Burdigalian in Europe.

The changes in the rhinocerotoid diversity seem to occur without direct outgroup interactions. We speculate that the less humid climate of the terminal Oligocene (Becker, 2003) could have been stressful for the anthracotheres. The tapirs also affiliated to forested areas were probably more specialized in their 


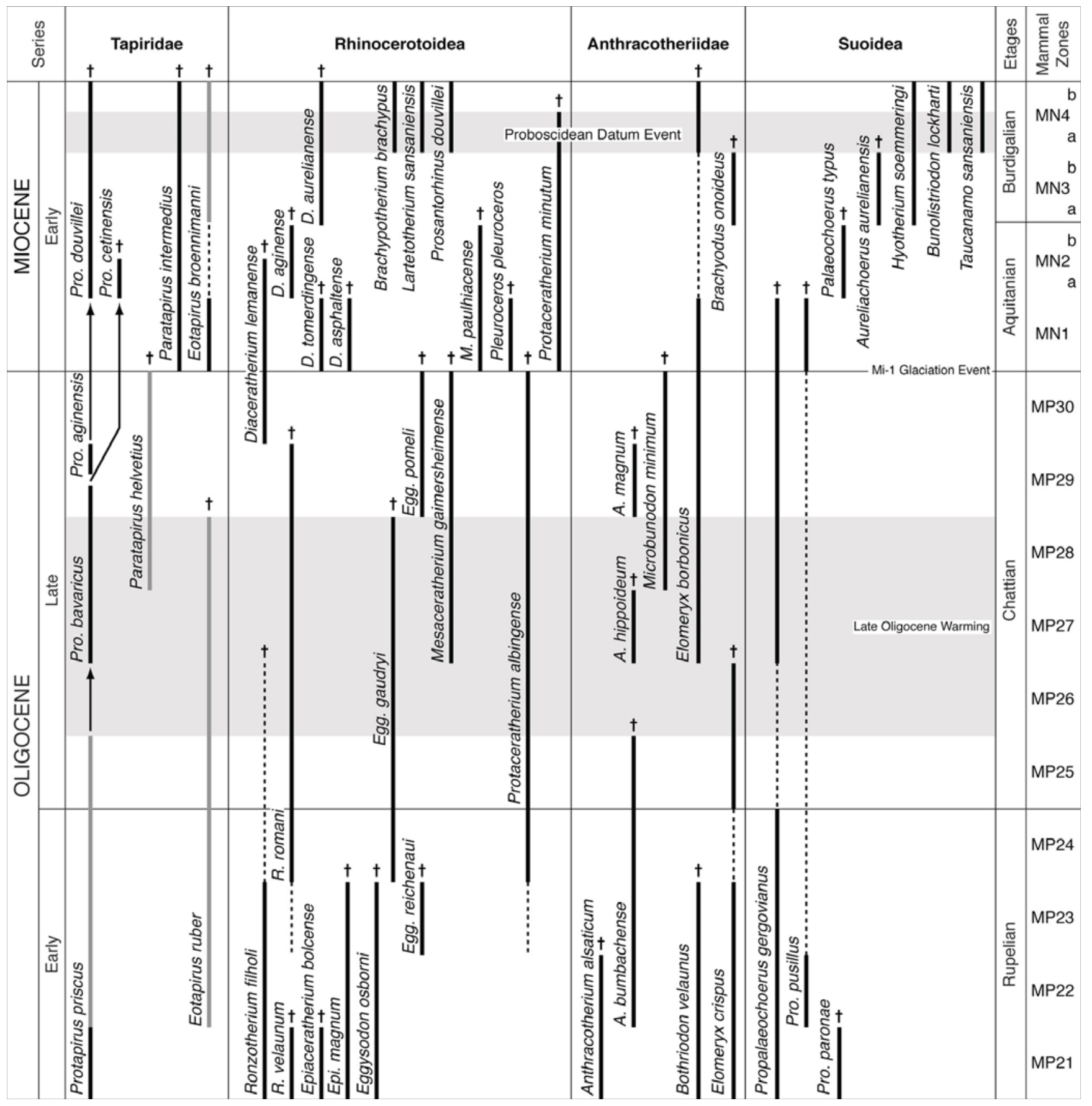

FIGURE 8. Biostratigraphic range of the genera of terrestrial ungulate mammals (Tapiridae: Heissig, 1978, 1999a; Cerdeño and Ginsburg, 1988; this study; Rhinocerotoidea: Heissig, 1999b; Uhlig, 1999; Antoine et al., 2000; Becker, 2003, 2009; Becker et al., 2009; pers. observ.; Anthracotheriidae: Stehlin, 1910; Hellmund, 1991; Ginsburg and Chevrier, 2005; Lihoreau and Ducrocq, 2007; Lihoreau et al., 2009; pers. observ.; and Suoidea: Hellmund, 1992; Fortelius et al., 1996) during the Oligocene and the early Miocene in Western Europe, related to main climatic and biotic events (Tassy, 1989; Vianey-Liaud, 1991; Zachos et al., 1997, 2001). Black lines: true occurrences; grey lines: poorly dated occurrences; dashed lines: uncertain occurrences; arrows: supposed speciations as stated in Cerdeño and Ginsburg (1988).

diet and social behavior but were probably less dependent on water supply than the semi-aquatic anthracotheriids. We speculate that the combination of competition and environmental changes could have been fatal to the anthracotheres. Thus, the tapirs may have adopted an opportunistic behavior when occupying the scarcer humid forested areas of the terminal Oligocene and in diversifying in the Aquitanian before the arrival of the suids in the Burdigalian. The latter were less specialized taxa in their diet and were uncommon during the Oligocene. However, successive migrations occurring in MN2 and MN3 with the arrival of Palaeochoerus, and Aureliachoerus and Hyotherium, respectively, have progressively affected the abundance of the tapirs. At the Proboscidean Datum Event, the intensive competition related to massive immigrations (among them the 
arrival of the suids Bunolistriodon and Taucanamo) may have led to the temporary disappearance of tapirs in Europe.

\section{CONCLUSION}

The review of the Tapiridae from the Swiss Molasse Basin during the Oligocene and the early Miocene enabled us to emend the diagnoses of three species of the genus Protapirus, $P$. bavaricus, $P$. aginensis, and $P$. douvillei, based primarily upon the relative development of the postfossae and cingula as well as to the presence or absence of a lingual pseudofossa on the upper premolars. The new data obtained in this study allowed us to establish a new and precise biostratigraphic range for the European tapir species from the early Oligocene to the early Miocene (from MP21 to MN4). Their paleoecology as forest animals associated with humid environments seems corroborated by the ecologic comparisons of the associated large-herbivorous mammals discovered in seven Swiss localities ranging from the late Oligocene to the late early Miocene (from MP27 to MN4). Furthermore, a general pattern of diversity and evolution has been established for large terrestrial mammals (Tapiridae, Rhinocerotoidea, Anthracotheriidae, and Suoidea) with a focus on the Oligocene-Miocene transition. During this time interval, the climatic and environmental variations were moderate, progressive, and associated with mammalian evolutionary patterns that consisted mainly of local and regional extinctions, successive colonisation events, and speciation. Additionally, the numerous immigrations and the drastic climatic and environmental changes linked to the Proboscidean Datum Event and the Miocene Climatic Optimum implied a more severe and faster faunal response.

\section{ACKNOWLEDGMENTS}

We thank NMB (L. Costeur, O. Schmidt), PIMUZ (H. Furrer), NMBE (U. Menkveld-Gfeller, B. Hostetter), MHNG (L. Cavin), NMSG (T. Bürgin), and U. Oberli (Sankt Gallen) for providing us access to the collections. We thank P. Vollenweider (NMBE) for taking the pictures of the tapir from Brüttelen 1. We thank L. Bocat and B. Mennecart for fruitful discussions, as well as A. Bianchi for improving the English of this manuscript. Editor R. Asher and reviewers K. Heissig and anonymous provided very helpful comments on this work. The University of Fribourg, the Swiss National Fund (project no. 126420), and the "Section d'archéologie et paléontologie" (Jura Canton) funded this research.

\section{LITERATURE CITED}

Antoine, P.-O., C. Bulot, and L. Ginsburg. 2000. Les rhinocérotidés (Mammalia, Perissodactyla) de l'Orléanien des bassins de la Garonne et de la Loire (France): intérêt biostratigraphique. Comptes Rendus de l'Académie des Sciences de Paris 330: 571-576.

Becker, D. 2003. Paléoécologie et paléoclimats de la Molasse du Jura (Oligo-Miocène): apport des Rhinocerotoidea (Mammalia) et des minéraux argileux. GeoFocus 9:1-328.

Becker, D. 2009. Earliest record of rhinocerotoids (Mammalia: Perissodactyla) from Switzerland: systematics and biostratigraphy. Swiss Journal of Geosciences 102:375-390.

Becker, D., T. Bürgin, U. Oberli, and L. Scherler. 2009. Diaceratherium lemanense (Rhinocerotidae) from Eschenbach (eastern Switzerland): systematics, palaeoecology, palaeobiogeography. Neues Jahrbuch für Geologie und Paläontologie Abhandlungen 254:5-39.

Berger, J.-P. 1985. La transgression de la Molasse marine supérieure (OMM) en Suisse occidentale. Münchner Geowissenschaften Abhandlungen, Reihe A 5:1-207.

Berger, J.-P. 1990. Floral changes in the Molasse of Western Switzerland (Oligo-Miocene): paleoclimatic implications; pp. 189-194 in
Proceeding Volume, Symposium on Paleofloristic and Paleoclimatic Changes in the Cretaceous and Tertiary, 1989, Prague.

Berger, J.-P. 1998. "Rochette" (Upper Oligocene, Swiss Molasse): a strange exemple of a fossil assemblage. Review of Palaeobotany and Palynology 101:95-110.

Berger, J.-P., B. Reichenbacher, D. Becker, M. Grimm, K. I. Grimm, L. Picot, A. Storni, C. Pirkenseer, C. Derer, and A. Schaefer. 2005. Paleogeography of the Upper Rhine Graben (URG) and the Swiss Molasse Basin (SMB) from Late Eocene to Pliocene. International Journal of Earth Sciences 94:697-710.

Blondel, C. 1998. Le squelette appendiculaire de sept ruminants oligocènes d'Europe; implications paléoécologiques. Comptes Rendus de l'Académie des Sciences de Paris 326:527-532.

Böhme, M. 2001. Die Landsäugerfauna des Unteroligozäns der Leipziger Bucht-Stratigraphie, Genese und Ökologie. Neues Jahrbuch für Geologie und Paläontologie Abhandlungen 220:63-82.

Böhme, M. 2003. The Miocene Climatic Optimum: evidence from ectothermic vertebrates of Central Europe. Palaeogeography, Palaeoclimatology, Palaeoecology 195:389-401.

Bolliger, T. 1992. Kleinsäugerstratigraphie in der miozänen Hörnlischüttung (Ostschweiz). Documenta Naturae 75:1-296.

Bolliger, T. 1997. The current knowledge of the biozonation with small mammals in the Upper Freshwater Molasse in Switzerland, especially the Hörnli-Fan; pp. 501-502 in J. P. Aguilar, S. Legendre, and J. Michaux (eds.), Actes du Congrès BiochroM'97. Mémoires et Travaux de l'Ecole pratique des Hautes Etudes, Institut Montpellier 21.

Brünnich, M. T. 1772. Zoologiae fundamenta praelectionibus academicis accomodata. Grunde i Dyrelaeren. F. C. Pelt, Hafniae et Lipsiae, $254 \mathrm{pp}$.

Cerdeño, E. 1988. Primeros datos sobre el esqueleto postcraneal de Protapirus cetinensis (Tapiridae). Geogaceta 5:21-24.

Cerdeño, E., and J. Morales. 1986. Los tapires del Mioceno inferior de España. Paleontología i Evolució 20:125-128.

Cerdeño, E., and L. Ginsburg. 1988. Les Tapiridae (Perissodactyla, Mammalia) de l'Oligocène et du Miocène inférieur européens. Annales de Paléontologie 74:71-96.

Colbert, M. W. 1999. Patterns of evolution and variation in the Tapiroidea (Mammalia: Perissodactyla). Ph.D. dissertation, The University of Texas at Austin, Austin, Texas, 464 pp.

Colbert, M. W., and R. M. Schoch. 1998. Tapiroidea and other moropomorphs; pp. 569-581 in C. M. Janis, K. M. Scott, and L. L. Jacobs (eds.), Evolution of Tertiary Mammals of North America. Volume 1: Terrestrial Carnivores, Ungulates and Ungulatelike Mammals. Cambridge University Press, Cambridge, U.K.

Costeur, L. 2009. Preliminary overview of regional endemism in European Neogene ungulates. Bulletin de la Société Géologique de France 180:17-25.

Depéret, C., and H. Douxami. 1902. Les Vertébrés oligocènes de Pyrimont-Challonges (Savoie). Mémoires de la Société Paléontologique Suisse 29:1-92.

Eberle, J. J. 2005. A new "tapir" from Ellesmere Island, Arctic Canada-implications for northern high latitude palaeobiogeography and tapir palaeobiology. Palaeogeography, Palaeoclimatology, Palaeoecology 227:311-322.

Eisenmann, V., and C. Guérin. 1992. Tapirus priscus from the Upper Miocene of Western Europe: palaeontology, biostratigraphy, and palaeoecology. Paleontología i Evolució 24-25:113-122.

Engesser, B. 1990. A preliminary mammal zonation of the Upper Marine Molasse of Switzerland; pp. 177-180 in E.-H. Lindsay, V. Fahlbusch, and P. Mein (eds.), European Neogene Mammal Chronology. NATO ASI Series (A), Volume 180. Plenum Press, New York.

Engesser, B., and N. A. Mayo. 1987. A biozonation of the Lower Freshwater Molasse (Oligocene and Agenian) of Switzerland and Savoy on the basis of fossil mammals. Münchner Geowissenschaften Abhandlungen 10:67-84.

Engesser, B., and C. Mödden. 1997. A new version of the biozonation of the Lower Freshwater Molasse (Oligocene and Agenian) of Switzerland and Savoy on the basis of fossil Mammals; pp. 475-499 in J.P. Aguilar, S. Legendre, and J. Michaux (eds.), Actes du Congrès BiochroM'97. Mémoires et Travaux de l'Ecole pratique des Hautes Etudes, Institut Montpellier 21.

Engesser, B., N. A. Mayo, and M. Weidmann. 1984. Nouveaux gisements de mammifères dans la Molasse subalpine vaudoise et fribourgeoise. Mémoires suisses de Paléontologie 107. 
Filhol, H. 1874. Note relative à la découverte d'un animal appartenant au genre des Tapirs dans les gisements de phosphates de chaux du Quercy. Mémoires de la Société Philosophique Naturelle:1-3.

Filhol, H. 1877. Recherches sur les Phosphorites du Quercy. Bibliothèque de l'Ecole des hautes Etudes, Paris 16:1-338.

Filhol, H. 1885. Observations sur le mémoire de M. Cope intitulé: relations des horizons renfermant des débris d'animaux fossiles en Europe et en Amérique. Annales de la Société Géologique 117:1-17.

Fortelius, M., J. Van Der Made, and R. L. Bernor. 1996. Middle and Late Miocene Suoidea of Central Europe and the Eastern Mediterranean: evolution, biogeography, and palaeoecology; pp. 348-379 in R. L. Bernor, V. Fahlbusch, and H. V. Mittmann (eds.), The Evolution of Western Eurasian Neogene Mammal Faunas, Columbia University Press, New York, New York.

Frei, H. P. 1979. Stratigraphische Untersuchung in der subalpinen Molasse der Nordost-Schweiz zwischen Wägitaler $\mathrm{Aa}$ und Urnäsch. Mitteilungen der Geologische Institute ETH-Zürich, N. F. 233:1-217.

Gaudry, A. 1897. La dentition des ancêtres de tapirs. Bulletin de la Société géologique de France, 3e série 25:315-325.

Ginsburg, L. 1980. Paléogéographie et âge de la mer des faluns d'après les mammifères. Mémoires de la Société d'Etudes Scientifiques d'Anjou 4:69-77.

Ginsburg, L., and F. Chevrier. 2005. Le genre Brachyodus (Artiodactyla, Mammalia) dans le Miocène du bassin de la Loire. Symbioses $12: 1-22$.

Ginsburg, L., and M. Hugueney. 1980. La faune de Mammifères du Miocène inférieur de Selles-sur-Cher (Loir-et-Cher). Bulletin du Muséum National d'Histoire Naturelle de Paris 2:271276.

Ginsburg, L., M. Bonneau, H. Bucher, E. Buge, H. Dineur, P. Janvier, P. Tassy, and M. T. Venec-Peyre. 1982. Les faunes de mammifères des sables continentaux miocènes inférieurs du synclinal d'Esvres au Nord de la Loire. Bulletin de la Société Géologique de France 24:403-406.

Gray, J. E. 1821. On the natural arrangement of vertebrose animals. London Medical Repository 15:296-310.

Haeckel, E. 1866. Generelle Morphologie der Organismen. Algemeine Entwicklingsgeschichte der Organismen. Kritische Grundzüge der mechanischen Wissenschaft von der enstehenden formen der Organismen, begründet durch die Descendenz-Theorie. 2 Volumes. Georg Reimer (Ed.), Berlin.

Heissig, K. 1978. Fossilführende Spaltenfüllungen Süddeutschlands und die Okologie ihrer oligozänen Huftiere. Mitteilungen der Bayerischen Staatsammlung für Paläontologie und historische Geologie, München 18:237-288.

Heissig, K. 1999a. Family Rhinocerotidae; pp. 175-188 in G. E. Rössner and K. Heissig (eds.), Land Mammals of Europe. Verlag Dr. Friedrich Pfeil, München.

Heissig, K. 1999b. Family Tapiridae; pp. 171-174 in G. E. Rössner and K. Heissig (eds.), Land Mammals of Europe. Verlag Dr. Friedrich Pfeil, München.

Hellmund, M. 1991. Revision der europäischen Species der Gattung Elomeryx Marsh 1894 (Anthracotheriidae, Artiodactyla, Mammalia)_Odontologische Untersuchung. Palaeontographica 220:1-101.

Hellmund, M. 1992. Schweineartige (Suina, Artiodactyla, Mammalia) aus oligo-miozänen Fundstellen Deutschlands, der Schweiz und Frankreichs. II. Revision von Palaeochoerus Pomel 1847 und Propalaeochoerus Stehlin 1899 (Tayasuidae). Stuttgarter Beitraege zur Naturkunde 189:1-75.

Holbrook, L. T. 1999. The phylogeny and classification of tapiromorph perissodactyls (Mammalia). Cladistics 15:331-350.

Hooker, J. J. 1989. Character polarities in early perissodactyls and their significane for Hyracotherium and infraordinal relationships; pp. 79-101 in D. R. Prothero and R. M. Schoch (eds.), The Evolution of Perissodactyls. Oxford University Press, New York.

Hugueney, M. 1997. Biochronologie mammalienne dans le Paléogènce et le Miocène inférieur du Centre de la France: synthèse réactualisée pp. 417-430 in J.-P. Aguilar, S. Legendre, and J. Michaux (eds.) Actes du Congrès BiochroM'97. Mémoires et Travaux de l'Ecole pratique des Hautes Etudes, Institut Montpellier 21.

Janis, C. M. 1984. Tapirs as living fossils; pp. 80-86 in N. Eldredge and S. M. Stanley (eds.), Living Fossils. Casebooks in Earth Sciences, New York.
Janis, C. M. 1989. A climatic explanation for patterns of evolutionary diversity in ungulate mammals. Palaeontology 32:463-481.

Kälin, D. 1997. The mammal zonation of the Upper Marine Molasse of Switzerland reconsidered. A local biozonation of MN2-MN5; pp. 581-590 in J.-P. Aguilar, S. Legendre, and J. Michaux (eds.), Actes du Congrès BiochroM'97. Mémoires et Travaux de l'Ecole pratique des Hautes Etudes, Institut Montpellier 21.

Kaup, J. J. 1833. Description d'ossements fossiles de mammifères inconnus jusqu'à présent qui se trouvent au Muséum Grand Ducal de Darmstadt. Heyer editions, Strasbourg, Paris 2e cahier:33-

Koenigswald, R. v. 1930. Die Tapirreste aus dem Aquitan von Ulm und Mainz. Palaeontographica 73:1-30.

Lihoreau, F., and S. Ducrocq. 2007. Family Anthracotheriidae; 89-105 in D. R. Prothero and S. E. Foss (eds.), The Evolution of Artiodactyls. The John Hopkins University Press, Baltimore.

Lihoreau, F., S. Ducrocq, P.-O. Antoine, M. Vianey-Liaud, S. Rafay, G. Garcia, and X. Valentin. 2009. First complete skulls of Elomeryx crispus (Gervais, 1849) and of Protaceratherium albigense (Roman, 1912) from a new Oligocene locality near Moissac (SW France). Journal of Vertebrate Paleontology 29:242-253.

Ludwig, A., F. Saxer, H. Eugster, and H. Fröhlicher. 1949. St. Gallen-Appenzell auf der topographischen Grundlage der Siegfried-Blätter: 222 Teufen, 223 Trogen, 224 Appenzel, 225 Kobelwald mit angrenzenden Teilen der Blätter: 79 St. Gallen, 219 Herisau und 272 Oberriet. Geologischer Atlas der Schweiz 1:25000 herausgegeben von der geologischen Komission der schweizerischen naturforschenden Gesellschaft Atlasblatt 23.

Luterbacher, H. P., J. R. Ali, H. Brinkhuis, F. M. Gradstein, J. J. Hooker, S. Monechi, J. G. Ogg, J. Powell, U. Röhl, A. Sanfilippo, and B. Schmitz. 2004. The Paleogene period; pp. 384-408 in F. M. Grad stein, J. G. Ogg, and A. G. Smith (eds.), A Geological Time Scale. Cambridge University Press, Cambridge, U.K.

Mein, P. 1989. Updating of MN zones; pp. 73-90 in E. H. Lindsay, V. Fahlbusch, and P. Mein (eds.), European Neogene Mammal Chronology. Plenum Press, New York.

Mein, P. 1999. European Miocene mammal biochronology; pp. 25-38 in G. E. Rössner and K. Heissig (eds.), Land Mammals of Europe. Verlag Dr. Friedrich Pfeil, München.

Meyer, H. v. 1867. Die fossilen Reste des genus Tapirus. Palaeontographica 7:159-200

Müller, W. H., M. Huber, A. Isler, and P. Kleboth. 1984. Geologische Karte der zentralen Nordschweiz 1:100 000 mit angrenzenden Gebieten von Baden-Württemberg. Erläuterungen. Herausgegeben von der Nationalen Genossenschaft für die Lagerung radioaktiver Abfälle (NAGRA) und der Schweizerischen Geologischen Kommission. Geologische Spezialkarte 121:1-150.

Nowak, R. M. 1999. Perissodactyla: Odd-toed Ungulates (Hoofed Mammals); pp. 1007-1040 in Walker's Mammals of the World, sixth edition, Volume 2. The John Hopkins University Press, Baltimore and London.

Oettingen-Spielberg, T. z. 1952. Ein oberoligocäner Tapirfund von Gaimersheim bei Ingoldstadt in Bayern. Neues Jahrbuch für Geologie und Paläontologie Abhandlungen 94:401-428.

Oettingen-Spielberg, T. z. 1958. Neue Tapirfunde aus dem Oberoligocän von Gaimersheim bei Ingolstadt. Neues Jahrbuch für Geologie und Paläontologie Abhandlungen 106:261-276.

Owen, R. 1848. Description of teeth and portions of jaws of two extinct Anthracotherioid quadrupeds (Hyopotamus vectianus and Hyop. bovinus) discovered by the Marchioness of Hastings in the Eocene deposits on the N. W. coast of the Isle of Wight; with an attempt to develop Cuvier's idea of the classification of pachyderms by the number of their toes. Quarterly Journal of the Geological Society of London 4:103-141.

Picot, L. 2002. Le Paléogène des synclinaux du Jura et de la bordure sud-rhénane: paléontologie (Ostracodes), paléoécologie, biostratigraphie et paléogéographie. GeoFocus 5:1-240.

Pomel, N. A. 1853. Catalogue méthodique et descriptif des vertébrés fossiles découverts dans le bassin hydrographique supérieur de la Loire et surtout dans la vallée de son affluent principal, l'Allier. J.B. Baillière (Ed.), Paris, 193 pp.

Prothero, D. R., and R. M. Schoch. 1989. Origin and evolution of the Perissodactyla: summary and synthesis; pp. 504-529 in D. R. Prothero and R. M. Schoch (eds.), The Evolution of Perissodactyls. Oxford University Press, New York 
Remy, J. A., J.-Y. Crochet, B. Sigé, J. Sudre, L. Bonis de, M. VianeyLiaud, M. Godinot, J.-L. Hartenberger, B. Lange-Badré, and B. Comte. 1987. Biochronologie des phosphorites du Quercy: mise à jour des listes fauniques et nouveaux gisements de mammifères fossiles. Münchner Geowissenschaften Abhandlungen, Reihe A 10:169-188.

Richard, M. 1938. Une nouvelle forme de Tapiridé oligocène. Tapirus (Protapirus) aginensis nov. sp. Bulletin de la Société Géologique de France 8:765-769.

Richard, M. 1948. Contribution à l'étude du Bassin d'Aquitaine. Les gisements de Mammifères tertiaires. Mémoires de la Société Géologique de France, Nouvelle Série 24:1-380.

Roman, F. 1919. Restes de mammifères terrestres des argiles aquitaniennes marines de Fontcaude près Montpellier. Bulletin de la Société Géologique de France 19:33-37.

Sach, V. J., and E. P. J. Heizmann. 2001. Stratigraphie und Säugetierfaunen der Brackwassermolasse in der Umgebung von Ulm (Südwestdeutschland). Stuttgarter Beiträge zur Naturkunde 310:1-96.

Schaub, S. 1928. Der Tapirschädel von Haslen. Ein Beitrag zur Revision der Oligocänen Tapiriden Europas. Mémoires de la Société Paléontologique Suisse 17:1-128.

Schaub, S., and J. Hürzeler. 1948. Die Säugetierfauna des Aquitanian vom Wischberg bei Langenthal. Eclogae geologicae Helveticae 41:354-366.

Schlosser, M. 1910. Über fossile Wirbletierreste aus dem Brüxer Braunkohlenbecken. Lotos 58:229-245.

Schlunegger, F., J. Melzer, and G. E. Tucker. 2001. Climate, exposed source-rock lithologies, crustal uplift and surface erosion: a theoretical analysis calibrated with data from the Alps/North Alpine Foreland Basin system. International Journal of Earth Sciences 90:484-499.

Schmidt-Kittler, N., M. Vianey-Liaud, C. Mödden, and B. Comte. 1997. New data for the correlation of mammal localities in the European Oligocene: biochronological relevance of the Theridomyidae; pp. 375-395 in J.-P. Aguilar, S. Legendre, and J. Michaux (eds.), Actes du Congrès BiochroM'97. Mémoires et Travaux de l'Ecole pratique des Hautes Etudes, Institut Montpellier 21.

Schoch, R. M. 1989. A review of the Tapiroids; pp. 298-320 in D. R. Prothero and R. M. Schoch (eds.), The Evolution of Perissodactyls. Oxford University Press, New York.

Stehlin, H. G. 1909. Remarques sur les faunules de mammifères des couches éocènes et oligocènes du basin de Paris. Bulletin de la Société Géologique de France 9:488-520.

Stehlin, H. G. 1910. Zur Revision der europäischen Anthracotherien. Verhandlungen der Naturforschenden Gesellschaft, Basel 21:165-185.
Steininger, F. F. 1999. Chronostratigraphy, geochronology and biochronology of the Miocene "European Land Mammal Mega-Zones" (ELMMZ) and the Miocene "Mammal-Zones" (MN-Zones); pp. 9-24 in G. E. Rössner and K. Heissig (eds.), Land Mammals of Europe. Verlag Dr. Friedrich Pfeil, München.

Studer, T. 1895. Die Säugetierreste aus den marinen Molasseablagerungen von Brüttelen. Mémoires de la Société Paléontologique Suisse 22:1-50.

Tassy, P. 1989. The "Proboscidean Datum Event": how many Proboscideans and how many events?; pp. 159-224 in E. H. Lindsay, V. Fahlbusch, and P. Mein (eds.), European Neogene Mammal Chronology. NATO ASI Series A, Vol. 180. Plenum Press, New York.

Uhlig, U. 1999. Die Rhinocerotoidea (Mammalia) aus der unteroligozänen Spaltenfüllung Möhren 13 bei Treuchtlingen in Bayern. Verlag der Bayerischen Akademie der Wissenschaften, München, $254 \mathrm{pp}$.

Vianey-Liaud, M. 1991. Les rongeurs de l'Eocène terminal et de l'Oligocène d'Europe comme indicateurs de leur environnement. Palaeogeography, Palaeoclimatology, Palaeoecology 85: $15-28$.

Viret, J. 1929. Les faunes de mammifères de l'Oligocène supérieur de la Limagne bourbonnaise. Annales de l'Université de Lyon, nouvelle série Sciences-Médecine 47.

Viret, J. 1958. Perissodactyla; pp. 368-475 in Traité de Paléontologie, Volume 6. Masson (Ed.), Paris.

Viret, J., and J. Hürzeler. 1937. Sur l'âge de la faune de mammifères de Pyrimont-Challonges. Bulletin de la Société Géologique de France, 5e série 7:129-140.

Whybrow, P. J., and P. Andrews. 2000. Response of Old World terrestrial vertebrate biotas to Neogene climate change. The last 145 million years; pp. 350-398 in S. J. Cluver and P. F. Rawson (eds.), Biotic Response to Global Change. Cambridge University Press, Cambridge, U.K.

Wood, H. E. 1937. Perissodactyl suborders. Journal of Mammalogy 18:106.

Zachos, J. C., B. P. Flower, and H. Paul. 1997. Orbitally paced climate oscillations across the Oligocene/Miocene boundary. Nature 388:567-570.

Zachos, J. C., M. Pagani, L. Sloan, E. Thomas, and K. Billups. 2001. Trends, rhythms, and aberrations in global climate 65 Ma to Present. Science 292:686-693.

Zittel, K. 1894. Traité de Paléontologie. V. Mammifères. Douin (Ed.), Paris, $806 \mathrm{pp}$ 